\title{
Landslide Dynamics: ISDR-ICL Landslide Interactive Teaching Tools (LITT)
}

\author{
Kyoji Sassa, Fausto Guzzetti, Hiromitsu Yamagishi, Željko Arbanas, \\ Nicola Casagli, Binod Tiwari, Ko-Fei Liu, Alexander Strom, \\ Mauri McSaveney, Eileen McSaveney, Khang Dang, \\ and Hendy Setiawan
}

\begin{abstract}
The International Consortium on Landslides (ICL) and ICL supporting organizations jointly established the ISDR-ICL Sendai Partnerships 2015-2025 which is the voluntary commitment to the Sendai Framework for Disaster Risk Reduction 2015-2030. As the core activity of the Sendai Partnerships, ICL has created "Landslide Dynamics: ISDR-ICL Landslide Interactive Teaching Tools", which are always updated and continuously improved, based on responses from users and lessons during their application. This paper describes the aim, outline, the contents of Text tools, PPT tools for lectures and PDF tools including already published reference papers/reports, guidelines, etc. Core parts of two fundamentals of the Teaching Tools, namely 1. Landslide types: description, illustration and photos, and 2. Landslide Dynamics for Risk Assessment are introduced.
\end{abstract}

\section{Keywords}

International consortium on landslides (ICL) - International strategy for disaster risk reduction (ISDR) • Landslide dynamics • Landslide types • Capacity development

K. Sassa $(\bowtie)$

International Consortium on Landslides (ICL), Kyoto, Japan e-mail: sassa@iclhq.org

F. Guzzetti

Istituto di Ricerca per la Protezione Idrogeologica, Consiglio Nazionale delle Ricerche, via Madonna Alta 126, 06128 Perugia, Italy

e-mail: Fausto.Guzzetti@irpi.cnr.it

H. Yamagishi

Asian Institute of Spatial Information, Shiroishi-Ku, Hongodori

2chome Kita 3-10, Sapporo, 003-0025, Japan

e-mail: hiromitsuyamagishi88@gmail.com

Ž. Arbanas

Faculty of Civil Engineering, University of Rijeka, Radmile

Matejčić 3 Rijeka 51000, Rijeka, Croatia

e-mail: zeljko.arbanas@gradri.uniri.hr

N. Casagli

Department of Earth Sciences, University of Firenze, Via La Pira

4, 50212 Florence, Italy

e-mail: nicola.casagli@unifi.it

B. Tiwari

Civil \& Environmental Engineering Department, California State

University, Fullerton, 800 N State College Blvd., E-419,

Fullerton, CA 92831, USA

e-mail: btiwari@fullerton.edu
K. Liu

National Taiwan University, No.1, Roosevelt Road, Chinese

Taipei, 10617, Taiwan, Republic of China

e-mail: kfliu@ntu.edu.tw

M. McSaveney $\cdot$ E. McSaveney

GNS Science, PO Box 30368, Lower Hutt, 5040, New Zealand e-mail: m.mcsaveney@gns.cri.nz

E. McSaveney

e-mail: e.mcsaveney@gns.cri.nz

H. Setiawan

Disaster Prevention Research Institute, Kyoto University, Uji, 611-0011, Japan

e-mail: hendy@flood.dpri.kyoto-u.ac.jp

\section{A. Strom}

Geodynamics Research Centre-branch of JSC "Hydroproject Institute", Volokolamsk Highway 2, Moscow, 125993, Russia e-mail: strom.alexandr@yandex.ru

K. Dang

International Consortium on Landslides, Kyoto, Japan

e-mail: khangdq@gmail.com

K. Dang

VNU University of Science, Hanoi, Vietnam 


\section{Aim of Landslide Dynamics: ISDR-ICL Landslide Interactive Teaching Tools}

The International Consortium on Landslides (ICL) proposed the ISDR-ICL Sendai Partnerships 2015-2025 for global promotion of understanding and reducing landslide disaster risk at a session of "Underlying risk factors" of the 3rd WCDRR on the morning of 16 March 2015. The partnership was proposed as a voluntary commitment to the World Conference on Disaster Risk Reduction, Sendai, Japan, 2015, and also as tools for implementing and monitoring the Post-2015 Framework for Disaster Risk Reduction and the Sustainable Development Goals. It was approved and signed by 16 global stakeholders in the afternoon of the same day in Sendai, Japan, and the Secretary-General Mr. Petteri Taalas of the World Meteorological Organization (WMO) signed it on 16 April 2016. The number of current ICL members (as of 30 November 2016) that are a part of the Sendai Partnerships is 64. The number will be updated every year. The signatory organizations may increase at the high-level panel discussion and the round-table discussion during the Fourth World Landslide Forum in Ljubljana, Slovenia in 2017. The Sendai Partnerships is being updated during the period.

The Sendai partnerships acknowledge that

- At a higher level, social and financial investment is vital for understanding and reducing landslide disaster risk, in particular social and institutional vulnerability, through coordination of policies, planning, research, capacity development, and the production of publications and tools that are accessible, available free of charge and are easy to use for everyone in both developing and developed countries.

Landslide science and technologies have continuously been developed to be more reliable, precise or cost-effective for landslide disaster risk reduction over the world. However, this scientific and technological progress has not been shared equally over the world. The gap between the available level of science and technologies and the practical use of those in many countries, regions and communities is very wide. To fill this gap, ICL has created Landslide Interactive Teaching Tools, which are always updated and continuously improved, based on responses from users and lessons during their application. All text books gradually become outdated. To avoid this problem, ICL plans to upload the latest teaching tools in the WEB of Teaching Tools and print text tools periodically.

\section{Landslide Dynamics}

A landslide is a downslope movement of rock, soil or both (Cruden 1991, 1996). Landslide disasters are caused by exposure to hazardous motions of soil and rock that threaten vulnerable human settlement in mountains, cities, coasts, and islands, as stated in the Sendai Partnerships. Understanding "Landslide dynamics" is the very basis of landslide disaster risk reduction.

\section{Organizations Contributing Teaching Tools}

Each teaching tool will be submitted by the teaching tool contributing organization as shown in the list of contribution organizations. Each organization has its own Teaching Tool Identifying Number consisting of telephone number of the country and the registered number within the country (Table 1). The involvement of organization as well as individual researcher is better to keep quality and updating of each tool.

\section{Outline of the ISDR-ICL Landslide Interactive Teaching Tools}

The teaching tools are classified in five major parts. The part number is included in each teaching tool identifier.

\section{0 . Fundamentals}

(1) Landslide Types: Description, illustrations and photos

(2) Landslide Dynamics for risk assessment

1. Mapping and Site Prediction

(1) Basic Mapping

(2) Site Prediction Using GIS

(3) Field Guidelines

2. Monitoring and Early Warning

(1) Remote Sensing Techniques for Landslide Monitoring

(2) Monitoring System Instrumentation

(3) Rainfall Threshold for Landslide Prediction

(4) Landslide Time Prediction from Pre-failure Movement Monitoring

(5) Guidelines for Landslide Monitoring and Early Warning Systems

3. Risk Assessment

(1) Numerical Modeling and Simulation

(2) Physical and Mathematical Modeling

(3) Laboratory Soil Testing for Landslide Analysis

(4) Analysis and Assessment of Landslides 
Table 1 List of contributing organizations with identifier number and email of leader

\begin{tabular}{|c|c|}
\hline Identifier No. & Organizations and email of leaders \\
\hline $001-1$ & $\begin{array}{l}\text { Department of Civil and Environmental Engineering, California State University, Fullerton, } 800 \text { N. State College Blvd., } \\
\text { E-419, Fullerton, CA } 92831 \\
\text { Binod Tiwari: <btiwari@fullerton.edu> }\end{array}$ \\
\hline $001-2$ & $\begin{array}{l}\text { U.S. Geological Survey (Denver Federal Ctr., Denver, CO } 80225 \text { USA) } \\
\text { Lynn Highland: <highland@usgs.gov> } \\
\text { Geological Survey of Canada (601 Booth St., Ottawa, Ontario, Canada KIA 0E8) } \\
\text { Peter Bobrowsky: <peter.bobrowsky@canada.ca> }\end{array}$ \\
\hline $007-1$ & $\begin{array}{l}\text { Sergeev Institute of Environmental Geoscience RAS, Ulansky per., 13, PB 145, Moscow 101000, Russia } \\
\text { Valentina Svalova <inter@geoenv.ru> }\end{array}$ \\
\hline $020-1$ & $\begin{array}{l}\text { Mining Department, Faculty of Engineering, Cairo University, } \\
\text { Giza - 12613, Egypt } \\
\text { Yasser ELSHAYEB <yasser.elshayeb@eng.cu.edu.e.g.> }\end{array}$ \\
\hline 034-1 & $\begin{array}{l}\text { Department of Civil and Environmental Engineering, Universitat Politècnica de Catalunya BarcelonaTech. Jordi Girona 1-3. } \\
08034 \text { Barcelona, Spain. } \\
\text { Jordi Corominas: <jordi.corominas@ @upc.edu> }\end{array}$ \\
\hline $034-2$ & $\begin{array}{l}\text { Catalan Institute for Water Research (ICRA), Emili Grahit 101, } 17003 \text { Girona, Spain. } \\
\text { Formerly at Sediment Transport Research Group (GITS), Department of Hydraulic, Marine, and Environmental Engineering, } \\
\text { Universitat Politècnica de Catalunya-BarcelonaTech (UPC) } \\
\text { Francesco Bregoli: < fbregoli@icra.cat> }\end{array}$ \\
\hline $039-1$ & $\begin{array}{l}\text { Research Institute for Geo-Hydrological Protection, CNR, via Madonna Alta 126, } 06128 \text { Perugia, Italy } \\
\text { Fausto Guzzetti <F.Guzzetti@irpi.cnr.it> }\end{array}$ \\
\hline $039-2$ & $\begin{array}{l}\text { ISPRA - Italian National Institute for Environmental Protection and Research, Geological Survey of Italy } \\
\text { Claudio Margottini: <claudio.margottini@isprambiente.it> }\end{array}$ \\
\hline $039-3$ & $\begin{array}{l}\text { Department of Earth Sciences, University of Firenze, Via La Pira 4, Firenze, Italy } \\
\text { Nicola Casagli: <nicola.casagli@ unifi.it> }\end{array}$ \\
\hline $039-4$ & $\begin{array}{l}\text { Department of Informatics, Modelling, Electronics and System Engineering, University of Calabria - Ponte Pietro Bucci, 41B } \\
\text { Building, 5th Floor, } 87036 \text { Arcavacata di Rende (CS) - Italy } \\
\text { Pasquale Versace: <pasquale.versace@ unical.it> }\end{array}$ \\
\hline 043-1 & $\begin{array}{l}\text { Institute of Mountain Risk Engineering, University of Natural Resources and Life Sciences, Peter-Jordan-Straße 82, Vienna, } \\
\text { A-1190, Austria } \\
\text { Johannes Hübl: <johannes.huebl@ @oku.ac.at> }\end{array}$ \\
\hline 044-1 & $\begin{array}{l}\text { Department of Civil \& Structural Engineering, University of Sheffield, Mappin St, Sheffield, United Kingdom. } \\
\text { Elisabeth T. Bowman: <e.bowman@ @heffield.ac.uk> }\end{array}$ \\
\hline $052-1$ & $\begin{array}{l}\text { Institute of Geography, National Autonomous University of Mexico (UNAM), Circuito Exterior, Ciudad Universitaria, } \\
\text { 04510, Coyoacán, Mexico City, Mexico } \\
\text { Irasema Alcántara-Ayala: <irasema@igg.unam.mx> }\end{array}$ \\
\hline $052-2$ & $\begin{array}{l}\text { Instituto de Geografía, Universidad Nacional Autónoma de México, México } \\
\text { Gabriel Legorreta Paulíni: <legorretag@ @otmail.com> }\end{array}$ \\
\hline 060-1 & $\begin{array}{l}\text { Slope Engineering Branch, } \\
\text { Jabatan Kerja Raya MALAYSIA }\end{array}$ \\
\hline $062-1$ & $\begin{array}{l}\text { Faculty of Engineering, Universitas Gadjah Mada, Indonesia } \\
\text { Dwikorita Karnawati: <dwiko@ugm.ac.id> } \\
\text { Teuku Faisal Fathani< tfathani@ugm.ac.id> }\end{array}$ \\
\hline 064-1 & $\begin{array}{l}\text { GNS Science, New Zealand } \\
\text { Mauri McSaveney }<\text { m.mcsaveney@gns.cri.nz> } \\
\text { Chris Massey <c.massey@gns.cri.nz> }\end{array}$ \\
\hline 066-1 & $\begin{array}{l}\text { Asian Disaster Preparedness Center (ADPC),Thailand } \\
\text { NMSI Arambepola <arambepola@adpc.net> }\end{array}$ \\
\hline $081-1$ & $\begin{array}{l}\text { ICL Headquarters, Japan } \\
\text { Kyoji Sassa <sassa@iclhq.org > }\end{array}$ \\
\hline $081-2$ & $\begin{array}{l}\text { Tohoku Gakuin University, Japan } \\
\text { Toyohiko Miyagi <miyagi@izcc.tohoku-gakuin.ac.jp> }\end{array}$ \\
\hline
\end{tabular}


Table 1 (continued)

\begin{tabular}{|c|c|}
\hline Identifier No. & Organizations and email of leaders \\
\hline $081-3$ & $\begin{array}{l}\text { Erosion and Sediment Control Department, Ministry of Land, Infrastructure, } \\
\text { Transport and Tourism (MLIT), Japan }\end{array}$ \\
\hline $081-4$ & $\begin{array}{l}\text { Asian Institute of Spatial Information, Shiroishi-ku, Hongodori 2chome kita 3-10 003-0025, Japan } \\
\text { Hiromitsu Yamagishi < hiromitsuyamagishi88@gmail.com> }\end{array}$ \\
\hline $081-5$ & $\begin{array}{l}\text { Center for Earth Information Science and Technology, Japan Agency for Marine-Earth Science and Technology, 3173-25 } \\
\text { Showamachi Kanazawa-ku, Yokohama Kanagawa 236-0001, Japan } \\
\text { Keiko Takahashi <takahasi@jamstec.go.jp> }\end{array}$ \\
\hline $0.81-6$ & $\begin{array}{l}\text { National Research and Development Agency, Public Works Research Institute (PWRI), Tsukuba, Japan } \\
\text { Jie Dou <j-dou@pwri.go.jp/douj888@gmail.com> }\end{array}$ \\
\hline $081-7$ & $\begin{array}{l}\text { Geosphere Engineering \& Disaster Management Office, International Consulting Operations, NIPPON KOEI CO., LTD., } \\
\text { 1-14-6 Kudan-kita Chiyoda-ku, Tokyo 102-8539, Japan } \\
\text { Kiyoharu Hirota <sbhirota@gmail.com> }\end{array}$ \\
\hline $081-8$ & $\begin{array}{l}\text { Department of Disaster prevention, Meteorology and Hydrology, Forestry and Forest Products Research Institute, } 1 \\
\text { Matsunosato, Tsukuba, Ibaraki 305-8687, Japan } \\
\text { Shiho Asano <shiho03@ ffpri.affrc.go.jp> }\end{array}$ \\
\hline $081-9$ & $\begin{array}{l}\text { Okuyama Boring Co., Ltd., Akita Japan } \\
\text { Shinro Abe <abeshinro@gmail.com> }\end{array}$ \\
\hline 084-1 & $\begin{array}{l}\text { VNU University of Science, Vietnam } \\
\text { DUC Do Minh<ducgeo@gmail.com> }\end{array}$ \\
\hline $084-2$ & $\begin{array}{l}\text { Vietnam Institute of Transport Science and Technology, Hanoi, Vietnam } \\
\text { Dinh Van Tien < dvtien.gbn@gmail.com> }\end{array}$ \\
\hline 084-3 & $\begin{array}{l}\text { Vietnam Institute of Geosciences and Mineral Resources, No. } 67 \text { Chien Thang street, Van Quan ward, Ha Dong district, } \\
\text { Hanoi City, Vietnam } \\
\text { Le Quoc Hung <le.quoc.hung@ vigmr.vn; hunglan@gmail.com> }\end{array}$ \\
\hline 086-1 & $\begin{array}{l}\text { Northeast Forestry University, Harbin, Heilongjiang, China } \\
\text { Wei Shan <shanwei456@163.com> }\end{array}$ \\
\hline $380-1$ & $\begin{array}{l}\text { ITGIS NASU (13, Chokolivsky Blvd., Kyiv, 03186, Ukraine) } \\
\text { Oleksander Trofymchuk <itelua@kv.ukrtel.net> }\end{array}$ \\
\hline $385-1$ & $\begin{array}{l}\text { Croatian Landslide Group from Faculty of Civil Engineering, Rijeka University } \\
\text { and Faculty of Mining, Geology and Petroleum Engineering, University of Zagreb } \\
\text { Željko Arbanas <zeljko.arbanas@ @radri.uniri.hr> } \\
\text { Snježana Mihalić Arbanas <snjezana.mihalic@rgn.hr> }\end{array}$ \\
\hline $386-1$ & $\begin{array}{l}\text { Faculty of Civil and Geodetic Engineering, University of Ljubljana, Jamova c. 2, Ljubljana, SI-1000, Slovenia } \\
\text { Matjaž Mikoš <matjaz.mikos@ @gg.uni-lj.si> } \\
\text { Nejc Bezak <nejc.bezak@fgg.uni-lj.si> }\end{array}$ \\
\hline $386-2$ & $\begin{array}{l}\text { Independent researcher and Associated Professor at the University of Nova Gorica, Slovenia } \\
\text { Marko Komac }<\text { m.komac@telemach.net> }\end{array}$ \\
\hline $504-1$ & $\begin{array}{l}\text { Honduras Earth Science Institute. National Autonomous University of Honduras. Ciudad Universitaria, Boulevard Suyapa } \\
\text { E-1. Tegucigalpa, Honduras. } \\
\text { Lidia Torres Bernhard <torres.lidia@unah.edu.hn> }\end{array}$ \\
\hline $504-2$ & $\begin{array}{l}\text { Faculty of Engineering, Central American Technological University, Zona Jacaleapa, Tegucigalpa, Honduras. } \\
\text { Rigoberto Moncada López <rigoberto.moncada@unitec.edu>, <rigoberto.moncada.lopez@ gmail.com> }\end{array}$ \\
\hline $886-1$ & $\begin{array}{l}\text { National Taiwan University, Department of Civil Engineering, Chinese Taipei } \\
\text { Ko-Fei Liu <kfliu@ntu.edu.tw> }\end{array}$ \\
\hline $886-2$ & $\begin{array}{l}\text { Department of Civil Engineering, National Chiao Tong University (Hsin Chu, 30010, Taiwan) } \\
\text { An-Bin Huang<huanganbin283@gmail.com> }\end{array}$ \\
\hline $886-3$ & $\begin{array}{l}\text { Soil and Water Conservation Bureau, Council of Agriculture (Nantou, 54044, Taiwan) } \\
\text { Hsiao-Yuan Yin <sammya@mail.swcb.gov.tw> }\end{array}$ \\
\hline $886-4$ & $\begin{array}{l}\text { Department of Hydraulic and Ocean Engineering, National Cheng Kung University, No. } 1 \text { University Road, Tainan 70101, } \\
\text { Taiwan } \\
\text { Chyan-Deng Jan <cdjan@mail.ncku.edu.tw> }\end{array}$ \\
\hline
\end{tabular}


Table 1 (continued)

\begin{tabular}{|l|l|}
\hline Identifier No. & Organizations and email of leaders \\
\hline 886-5 & $\begin{array}{l}\text { Socio-Economic System Division, National Science \& Technology Center for Disaster Reduction, Taiwan, R.O.C. } \\
\text { Hsin-Chi Li <hsinchi@ @cdr.nat.gov.tw> }\end{array}$ \\
\hline 886-6 & $\begin{array}{l}\text { Department of Soil and Water Conservation, National Chung Hsing University, (Taichung, 402, Taiwan, R.O.C.) } \\
\text { Su-Chin Chen <scchen@ @ragon.nchu.edu.tw> }\end{array}$ \\
\hline 886-7 & $\begin{array}{l}\text { Water Environment Research Center, National Taipei University of Technology, 1, Sec. 3, Chung-Hsiao E. Rd., Taipei 106, } \\
\text { Taiwan } \\
\text { Chia-Chun Ho <ccho@ ntut.edu.tw> }\end{array}$ \\
\hline
\end{tabular}

4. Risk Management and Country Practices

(1) Landslide Risk Management

(2) Community Risk Management

(3) Country Practices.

The teaching tools consist of three types of tools.

1. The first type are text-tools consisting of original texts with figures. The first edition includes two volumes of books.

2. The second type are PPT-tools consisting of PowerPoint files and video tools made for visual lectures.

3. The third type are PDF-tools consisting of already published reference papers/reports, guidelines, laws and others.

The second and the third type of tools are supplementary tools of the text tools (text books).

Each teaching tool has its own identifier. The identifier of each tool consists of three parts:

1. the number of the part of the tool box in which it appears (Parts 0-4);

2. the country telephone code and an assigned unique number for each contributing organization (for example 081-1 signifies Japan-ICL headquarters, and 081-3 signifies Japan - Erosion and Sediment Control Department, Ministry of Land, Infrastructure, Transport and Tourism);

3. the last part of the identifier is a consecutive number assigned to the teaching tool by its contributing organization.

The following tables (Tables 1, 2, 3 and 4) present the list of contributing organizations and the list of contents of the teaching tools.

\section{Fundamentals of the ISDR-ICL Landslide Interactive Teaching Tools (LITT)}

All tools include visual explainations with many full color illustrations and photos. The tools start from two fundamental tools (TXT Tool 0.001-2.1 and TXT Tool 0.081-1.1).
To present examples and illustration and photos used in LITT and also present an overview of the content of two fundamental aspects, some selected illustrations and photos are presented below.

\section{Landslide Types: Descriptions, Illustrations and Photos}

All figures and captions are copied from TXT Tool 0.001-2.1. Fig. 1.

The definitions of landslides were not uniform around the world before the United Nations International Decade for Natural Disaster Reduction (IDNDR) 1990-2000. Landslide disasters are one of the major disasters to be tackled in IDNDR. The united definition of landslides forms the basis for investigations and statistics of landslide disasters, through IDNDR as its base. The International Geotechnical Societies and UNESCO Working Group for World Landslide Inventory (Chair: David Cruden) was established. The landslide was then defined to be "the movement of a mass of rock, debris or earth down a slope". The types were explained in detail in "Landslides-investigation and mitigation", edited by A Keith Turner and Robert L, Schuster, Special Report 247 of the National Research Council (U.S.) Transportation Research Board in 1996. In order to disseminate this definition of landslides, including debris flows, rock falls and others, Lynn Highland and Peter Bobrowsky implemented the IPL 106 Best Practice handbook for landslide hazard mitigation (2002-2007) to create a handbook on landslides and published its result as "The Landslide Handbook-A guide to Understanding Landslides" (USGS Circular 1325) (Highland and Bobrowsky 2008). This book was well evaluated and translated into several languages. This project was awarded an "IPL Award for Success" at the Second World Landslide Forum at FAO Headquarters, Rome, October 2011. This definition, which includes debris flows, rock falls and other different types of landslides, is the basis of landslide science and it is the base of the International Journal "Landslides" founded in 2004. TXT Tool 0.001-2.1 (Highland and Bobrowsky 2017) presents many photos and illustrations to explain this definition by IDNDR, 
Table 2 Contents of text tools

Landslide dynamics: ISDR-ICL landslide interactive teaching tools Vol. 1 fundamental, mapping and monitoring Kyoji Sassa, Fausto Guzzetti, Hiromitsu Yamagishi, Zeljko Arbanas, Nicola Casagli, Mauri McSaveney, Khang Dang Editors

\begin{tabular}{l|l|l|l} 
No. & Identifier & Title & Author
\end{tabular}

\section{Fundamentals}

1. TXT-Tool 0.001-2.1 Landslide types: descriptions, illustrations and photos

2. TXT-Tool 0.081-1.1 Landslide dynamics for risk assessment

Part 1. Mapping and site prediction

I.1 Basic mapping

1. TXT-Tool 1.081-2.1 Landslide mapping through the interpretation of aerial photographs

2. TXT-Tool 1.081-2.2 Landslide mapping through the interpretation of aerial photographs and topographic maps

3. TXT-Tool 1.081-3.1 Landslide recognition and mapping using aerial photographs and Google Earth

4. TXT-Tool 1.039-1.1 Very-high resolution stereoscopic satellite images for landslide mapping

5. TXT-Tool 1.504-1.1 Landslide Inventory educational methodology derived from experiences in Latin America

I.2 Site prediction using GIS

6. TXT-Tool 1.052-1.1 GIS using landslides Inventory mapping for Volcanoes

7. TXT-Tool 1.052-1.2 GIS using landslides susceptibility mapping model for Volcanoes

8. TXT-Tool 1.504-1.1

9. TXT-Tool 1.386-2.1

Landslide susceptibility assessment method

A comparative study of the binary logistic regression (BLR) and artificial neural network (ANN) models for GIS-based spatial predicting landslides at a regional scale

10. TXT-Tool 1.386-2.2 Practical approach to assessing the factors influencing landslide susceptibility modelling - a case of Slovenia

11. TXT-Tool 1.084-3.1 Landslide susceptibility mapping at regional scale in Vietnam

12. TXT-Tool 1.039-1.2 Bedding attitude information through the interpretation of stereoscopic aerial photographs and GIS modeling

13. TXT-Tool 1.086-1.1 Distribution of Isolated Patches Permafrost in the Lesser Khingan Mountains of Northeast China using Landsat7 ETM + Imagery

I.3 Field guidelines
14. TXT-Tool 1.081-7.1

15. TXT-Tool 1.064-1.

Investigating landslides in the field Using Google Earth and PowerPoint: a case study of Altos de Loarque in Honduras

Field guide for the identification and assessment of landslide and erosion features and related hazards affecting pipelines

Part 2. Monitoring and early warning

II.1 Remote sensing techniques for landslide monitoring

1. TXT-Tool 2.039-3.1 Satellite remote sensing techniques for landslides detection and mapping

2. TXT-Tool 2.039-3.2 Ground-based remote sensing techniques for landslides detection, monitoring and early warning

3. TXT-Tool 2.386-2.1 SAR interferometry as a tool for detection of landslides in early phases

4. TXT-Tool 2.039-3.3 Ground-based radar interferometry for landslide monitoring

II.2 Monitoring system instrumentation

5. TXT-Tool 2.062-1.1 A Landslide monitoring and early warning system

6. TXT-Tool 2.007-1.1 Monitoring alarm system of landslide and seismic safety for potentially hazardous objects
Lynn Highland, Peter

Bobrowsky

Kyoji Sassa, Khang Dang

Toyohiko Miyagi

Eisaku Hamasaki et al.

Hiromitsu Yamagishi, Rigoberto Moncada Lopez

Francesca Ardizzone et al.

Rigoberto Moncada Lopez, Hiromitsu Yamagishi

Gabriel Legorreta Paulin

Gabriel Legorreta Paulín, Michael Polenz, Trevor Contreras

Marko Komac, Jernej Jež

Jie Dou et al.

\section{Marko Komac}

Le Quoc Hung et al.

Ivan Marchesini et al.

Chunjiao Wang, Wei Shan

Kiyoharu Hirota

Chris Massey et al.

Nicola Casagli et al.

Nicola Casagli, Stefano Morelli et al.

M. Komac, T. Peternel, M. Jemec

Nicola Casagli et al.

Teuku Faisal Fathani, Dwikorita Karnawati

Alexander Ginzburg et al. 
Table 2 (continued)

Landslide dynamics: ISDR-ICL landslide interactive teaching tools Vol. 1 fundamental, mapping and monitoring Kyoji Sassa, Fausto Guzzetti, Hiromitsu Yamagishi, Zeljko Arbanas, Nicola Casagli, Mauri McSaveney, Khang Dang Editors

\begin{tabular}{|l|l|l|l|l}
\hline No. & Identifier & Title & Author \\
\hline 7. & TXT-Tool 2.007-1.2 & $\begin{array}{l}\text { Landslide and seismic monitoring system on the base of unified automatic } \\
\text { equipment }\end{array}$ & Alexander Ginzburg et al. \\
\hline
\end{tabular}

II.3 Rainfall threshold for landslides prediction

8. TXT-Tool 2.039-1.1 Italian national landslide warning system

9. TXT-Tool 2.084-3.1 Rainfall thresholds for triggering Geohazards in Bac Kan Province (Vietnam)

10. TXT-Tool 2.039-1.2 Rainfall thresholds for the possible initiation of shallow landslides in the Italian Alps

11. TXT-Tool 2.039-1.3 Topographic and pedological rainfall thresholds for the prediction of shallow landslides in central Italy

12. TXT-Tool 2.039-4.1 FLaIR model (Forecasting of Landslides Induced by $\underline{\text { Rainfalls) }}$

13. TXT-Tool 2.386-2.1 A system to forecast rainfall induced landslides in Slovenia

14. TXT-Tool 2.886-1.1 Early warning criteria for debris flows and their application in Taiwan

15. TXT-Tool 2.081-5.1 High-resolution rainfall prediction for early warning of landslides

16. TXT-Tool 2.386-1.1 Intensity-Duration Curves for Rainfall-Induced Shallow Landslides and Debris Flows Using Copula Functions

17. TXT-Tool 2.039-1.5 An algorithm for the objective reconstruction of rainfall events responsible for landslides

Mauro Rossi et al.

Nguyen Duc Ha et al.

Maria Teresa Brunetti et al.

Silvia Peruccacci, Maria Teresa Brunetti et al.

Pasquale Versace et al.

Mateja Jemec Auflič et al.

Chyan-Deng Jan et al.

Ryo Onishi et al.

Nejc Bezak et al.

Massimo Melillo et al.

II.4 Landslide time prediction from pre-failure movement monitoring

18. TXT-Tool 2.385-1.1 A comprehensive landslide monitoring system: the Kostanjek landslide, Croatia

19. TXT-Tool 2.385-1.2 Landslide comprehensive monitoring system: the grohovo landslide case study, Croatia

20. TXT-Tool 2.062-1.2 A monitoring and early warning system for debris flows in rivers on Volcanoes

21. TXT-Tool 2.380-1.1 Monitoring and early warning system of the building constructions of the Livadia Palace, Ukraine

22. TXT-Tool 2.039-4.2 LEWIS project: An Integrated System For Landslides Early Warning

23. TXT-Tool 2.039-3.4 Methods to improve the reliability of time of slope failure predictions and to setup alarm levels based on the inverse velocity method

Snježana Mihalić Arbanas et al.

Željko Arbanas et al.

Teuku Faisal Fathani, Djoko Legono

O. Trofymchuk, I. Kaliukh, O. Klimenkov

Pasquale Versace et al.

Tommaso Carlà et al.

II.5 Guidelines for landslides monitoring and early warning systems

24. TXT-Tool 2.886-1.2 Guidelines for landslide monitoring systems

25. TXT-Tool 2.386-1.2 Practice guideline on monitoring and warning technology for debris flows

26. TXT-Tool 2.886-1.3 Debris flow monitoring guidelines

An-Bin Huang, Wen-Jong Chang

Johannes Hübl, Matjaž Mikoš

Hsiao-Yuan Yin, Yi-Min

Huang

Back material

1.

List of PDF-tools and PPT-tools

2.

ICL structure

Landslide dynamics: ISDR-ICL landslide interactive teaching tools Vol. 2 testing, risk management and country practice Kyoji Sassa, Binod Tiwari, Kofei Liu, Mauri McSaveney, Eileen McSaveney Alexander Strom, Hendy Setiawan editors

\begin{tabular}{l|l|l|l|l}
\hline No. & Identifier & Title & Author
\end{tabular}

Part 3. Risk assessment

III.1 Numerical modeling and simulation

1. TXT-Tool 3.081-1.1 An integrated model simulating the initiation and motion of earthquake and rain induced rapid landslides and its application to the 2006 Leyte landslide

2. TXT-Tool 3.385-1.1 Application of Integrated Landslide Simulation Model LS-Rapid to the Kostanjek Landslide, Zagreb, Croatia

Pham Van Tien, Kyoji Sassa, Khang Dang

Karolina Gradiški et al. 
Table 2 (continued)

Landslide dynamics: ISDR-ICL landslide interactive teaching tools Vol. 2 testing, risk management and country practice Kyoji Sassa, Binod Tiwari, Kofei Liu, Mauri McSaveney, Eileen McSaveney Alexander Strom, Hendy Setiawan editors

\begin{tabular}{|l|l|l|}
\hline No. & Identifier & Title \\
\hline 3. & TXT-Tool 3.081-1.2 & $\begin{array}{l}\text { Simulation of landslide induced tsunami (LS-Tsunami) based on the } \\
\text { landslide motion predicted by LS-RAPID }\end{array}$ \\
\hline 4. & TXT-Tool 3.081-1.3 & $\begin{array}{l}\text { A hypothesis of the Senoumi submarine megaslide in Suruga Bay in Japan } \\
\text { based on the undrained dynamic-loading ring shear tests and computer } \\
\text { simulation }\end{array}$ \\
\hline 5. & TXT-Tool 3.081-1.4 & $\begin{array}{l}\text { Initiation Mechanism of Rapid and Long Runout Landslide and Simulation } \\
\text { of Hiroshima Landslide Disasters using the Integrated Simulation Model } \\
\text { (LS-RAPID) }\end{array}$ \\
\hline
\end{tabular}

6. TXT-Tool 3.385-1.2 Deterministic landslide susceptibility analyses using LS-Rapid software

7. TXT-Tool 3.886-1.1 Debris2D tutorial

8. TXT-Tool 3.081-1.5 Manual for the LS-RAPID software

9. TXT-Tool 3.034-2.1 A debris flow regional fast hazard assessment tool

10. TXT-Tool 3.386-1.1 Two-dimensional debris-flow modelling and topographic data

11. TXT-Tool 3.886-1.2 Simulation for the debris flow and sediment transport in a large-scale watershed

12. TXT-Tool 3.385-1.3 Landslide occurrence prediction in the Rječina River Valley as a base for an early warning system

III.2 Physical and mathematical modeling

13. TXT-Tool 3.001-1.1 Physical modelling of rain-induced landslides

14. TXT-Tool 3.001-1.2 Physical modeling of earthquake-induced landslides

15. TXT-Tool 3.044-1.1 The runout of chalk cliff collapses in England and France - case studies and physical model experiments

16. TXT-Tool 3.007-1.1 Mechanical-mathematical modeling and monitoring for landslide processes

III.3 Laboratory soil testing for landslide analysis

17. TXT-Tool 3.081-1.6 Manual for undrained dynamic-loading ring shear apparatus

18. TXT-Tool 3.081-1.7 Undrained dynamic-loading ring shear apparatus and its application to landslide dynamics

19. TXT-Tool 3.081-1.8 A new high-stress undrained ring-shear apparatus and its application to the 1792 Unzen-Mayuyama megaslide in Japan

20. TXT-Tool 3.001-1.3 Laboratory measurement of fully softened shear strength and its application for landslide analysis

III.4 Analysis and assessment of landslides

21. TXT-Tool 3.081-1.9 Dynamic properties of earthquake induced large-scale rapid landslides within past landslide masses

22. TXT-Tool 3.001-1.4 Using excel tools for slope stability analysis

23. TXT-Tool 3.034-1.1 A textural classification of argillaceous

Rocks and their durability

24. TXT-Tool 3.039-1.1 Landslide-related WPS Services

Author

Khang Dang, Kyoji Sassa

Hendy Setiawan, Kyoji Sassa, $\mathrm{Bin} \mathrm{He}$

Loi Doan Huy et al.

Sanja Dugonjić Jovančević et al.

Ko-Fei LIU, Ying-Hsin WU

Kyoji Sassa, Hendy Setiawan et al.

F. Bregoli et al.

Jošt Sodnik, Matjaž Mikoš

Ying-Hsin Wu et al.

Martina Vivoda et al.

Binod Tiwari, Beena Ajmera

Beena Ajmera and Binod Tiwari

E. T. Bowman, W. A. Take

Svalova Valentina

Hendy Setiawan et al.

Hendy Setiawan et al.

Khang Dang et al.

Binod Tiwari, Beena Ajmera

Pham Van Tien, Kyoji Sassa

Beena Ajmera, Binod Tiwari

J. Corominas,

J. Martínez-Bofill, A. Soler

Ivan Marchesini,

Massimiliano Alvioli, Mauro Rossi

\section{Part (4) Risk management and country practices}

\section{IV.1 Landslide risk management}

1. TXT-Tool 4.084-1.1 Soil slope stability analysis

2. TXT-Tool 4.081-2.1 Risk Evaluation using the Analytic Hierarchy Process (AHP) Introduction to the process concept

3. TXT-Tool 4.039-3.1 Terrestrial laser scanner and geomechanical surveys for the rapid evaluation of rock fall susceptibility scenarios

Do Minh DUC

Eisaku HAMASAKI, Toyohiko MIYAGI

Gigli, G. et al. 
Table 2 (continued)

Landslide dynamics: ISDR-ICL landslide interactive teaching tools Vol. 2 testing, risk management and country practice Kyoji Sassa, Binod Tiwari, Kofei Liu, Mauri McSaveney, Eileen McSaveney Alexander Strom, Hendy Setiawan editors

\begin{tabular}{|l|l|l|}
\hline No. & Identifier & Title \\
\hline 4. & TXT-Tool 4.039-3.2 & $\begin{array}{l}\text { How to assess landslide activity and intensity with Persistent Scatterer } \\
\text { Interferometry (PSI): the PSI-based matrix approach }\end{array}$ \\
\hline
\end{tabular}

Author

5. TXT-Tool 4.034-1.1 Quantitative rockfall risk assessment for roadways and railways

6. TXT-Tool 4.084-1.2 Landslide Vulnerability assessment: a case study of Backan Town, Northeast Vietnam

7. TXT-Tool 4.086-1.1 Landslide investigations in the northwest section of the Lesser Khingan Range in China using combined HDR and GPR methods

8. TXT-Tool 4.052-1.1 Landslide risk perception

9. TXT-Tool 4.886-1.1 Taiwan Typhoon Loss Assessment System (TLAS Taiwan) Web Tool

10. TXT-Tool 4.385-1.1 Method for prediction of landslide movements based on random forests

IV.2 Community risk management

11. TXT-Tool 4.062-1.1 Community hazard maps for landslide risk reduction

12. TXT-Tool 4.039-1.1 Definition and use of empirical rainfall thresholds for possible landslide occurrence

13. TXT-Tool 4.062-1.2 A socio-technical approach for landslide mitigation and risk reduction

14. TXT-Tool 4.066-1.1 Community-based Landslide risk management approaches

15. TXT-Tool 4.039-2.1 On the protection of cultural heritages from landslides

IV.3 Country practices

16. TXT-Tool 4.886-1.2 Procedures for constructing disaster evacuation maps: guidelines and standards

17. TXT-Tool 4.886-1.3 Emergency post-landslide disaster documentation

18. TXT-Tool 4.386-1.1 State-of-the-art overview on landslide disaster risk reduction in Slovenia

19. TXT-Tool 4.086-1.2 Shallow landslides and plant protection in seasonal frozen regions

20. TXT-Tool 4.886-1.4 Ecological countermeasure guidelines and case histories in Taiwan

21. TXT-Tool 4.086-1.3 The impact of climate change on landslides in Southeastern high-latitude permafrost regions of China

22. TXT-Tool 4.052-1.2 Landslide risk communication

23. TXT-Tool 4.504-1.1 How to make a database of landslides in Tegucigalpa, Honduras

24. TXT-Tool 4.039-3.3 Debris flows modeling for hazard mapping

25. TXT-Tool 4.039-4.1 Landslide investigations and risk mitigation. The Sarno, Italy, case study

26. TXT-Tool 4.081-8.1 Landslide monitoring for early warning in the Hai van station landslide in Vietnam

27. TXT-Tool 4.081-1.1 Mechanism of large-scale deep-seated landslides induced by rainfall in gravitationally deformed slopes: A case study of the Kuridaira landslide in Kii Peninsula

28. TXT-Tool 4.081-9.1 Rotary sampling drilling technology to extract a core of high quality by using sleeve-incorporating core barrel and polymer mud-From the cases of drilling in the landslide area of Japan and Vietnam

29. TXT-Tool 4.081-1.2 Mechanism of the Aratozawa large-scale landslide induced by the 2008 Iwate-Miyagi Earthquake

Cigna, F., Bianchini, S., Casagli, N.

Olga Mavrouli, Jordi Corominas

Do Minh Duc et al.

Zhaoguang $\mathrm{Hu}$, Wei Shan, Hua Jiang

Irasema Alcántara Ayala

Hsin-Chi Li, Yi-Chen Chen, Mei-Chun Kuo

Martin Krkač et al.

Dwikorita Karnawati et al.

Silvia Peruccacci, Maria

Teresa Brunetti

Dwikorita Karnawati et al.

Asian Disaster Preparedness Centre (ADPC)

Claudio Margottini

Su-Chin Chen, Lien-Kuang Chen

Lien-Kuang Chen

Matjaž Mikoš et al.

Ying Guo et al.

Chia-Chun $\mathrm{HO}$ et al.

Wei Shan, Zhaoguang $\mathrm{Hu}$, Ying Guo

Irasema Alcántara Ayala

Lidia Torres Bernhard et al. Massimiliano Nocentini et al.

Giovanna Capparelli, Luciano Picarelli, Pasquale Versace

Shiho Asano, Hirotaka Ochiai, Huynh Dang Vinh

Pham Van Tien et al.

Shinro Abe et al.

Hendy Setiawan et al.

\section{Back material}

1.

List of PDF-tools and PPT-tools

2.

ICL structure 
Table 3 Contents of PPT tools and video tools

\begin{tabular}{|c|c|c|c|}
\hline \multicolumn{4}{|c|}{ List of PPT tools \& video tools } \\
\hline No. & Identifier & Title & Author \\
\hline 1. & PPT-tool 1.039-1.1 & $\begin{array}{l}\text { Remote Sensing data and methodology for event landslide recognition } \\
\text { and mapping }\end{array}$ & Alessandro Mondini \\
\hline 2. & PPT-tool 1.052-1.1 & Logisnet Manual and Quick-start Tutorial & $\begin{array}{l}\text { Gabriel Legorreta Paulín, } \\
\text { Marcus I. Bursik }\end{array}$ \\
\hline 3. & PPT-tool 2.039-1.1 & Italian National Landslide Warning System (29 pages) & Mauro ROSSI et al. \\
\hline 4. & PPT-tool 2.062-1.1 & Landslide Monitoring and Early Warning System & $\begin{array}{l}\text { Teuku Faisal FATHANI, } \\
\text { Dwikorita KARNAWATI }\end{array}$ \\
\hline 5. & PPT-tool 2.062-1.2 & $\begin{array}{l}\text { Monitoring and Early Warning System for Debris Flows in Rivers on } \\
\text { Volcanoes ( } 37 \text { pages) }\end{array}$ & $\begin{array}{l}\text { Teuku Faisal FATHANI, } \\
\text { Djoko LEGONO }\end{array}$ \\
\hline 6. & PPT-tool 2.385-1.2 & $\begin{array}{l}\text { Landslide Comprehensive Monitoring System: The Grohovo Landslide } \\
\text { Case Study, Croatia }\end{array}$ & Željko ARBANAS et al. \\
\hline 7. & PPT-Tool 3.385-1.3 & $\begin{array}{l}\text { Landslide Occurrence Prediction in the Rječina River Valley as a Base for } \\
\text { an Early Warning System }\end{array}$ & $\begin{array}{l}\text { Martina VIVODA PRODAN } \\
\text { et al. }\end{array}$ \\
\hline 8. & PPT-tool 2.886-1.2 & Landslide Monitoring and Warning & $\begin{array}{l}\text { An-Bin HUANG, Wen-Jong } \\
\text { Chang }\end{array}$ \\
\hline 9. & PPT-tool 3.039-1.1 & Landslide Hazards and Risk Assessment & Fausto GUZZETTI \\
\hline 10. & PPT-tool 3.039-1.2 & Landslide-related WPS services & Ivan MARCHESINI \\
\hline 11. & PPT-tool 3.039-1.3 & Probabilistic approach to physically based landslide modeling & Massimiliano ALVIOLI et al. \\
\hline 12. & PPT-tool 3.039-1.4 & $\begin{array}{l}\text { Advanced 2D Slope stability Analysis by LEM by SSAP software: a full } \\
\text { freeware tool for teaching and scientific community }\end{array}$ & Lorenzo BORSELLI \\
\hline 13. & PPT-tool 3.886-1.1 & Debris-2D Tutorial & Ko-Fei LIU, Ying-Hsin WU \\
\hline 14. & PPT-tool 4.039-1.1 & $\begin{array}{l}\text { Definition and Use of Empirical Rainfall Thresholds for Possible } \\
\text { Landslide Occurrence }\end{array}$ & $\begin{array}{l}\text { Maria Teresa BRUNETTI, } \\
\text { Silvia PERUCCACCI }\end{array}$ \\
\hline 15. & PPT-tool 4.039-1.2 & Landslide Risk to the Population of Italy & $\begin{array}{l}\text { Paola SALVATI, Cinzia } \\
\text { BIANCHI }\end{array}$ \\
\hline 16. & PPT-tool 4.062-1.1 & Socio-Technical Approach for Landslide Mitigation and Risk Reduction & $\begin{array}{l}\text { Dwikorita KARNAWATI } \\
\text { et al. }\end{array}$ \\
\hline 17. & PPT-tool 4.062-1.2 & Community Hazard Maps for Landslide Risk Reduction & $\begin{array}{l}\text { Dwikorita KARNAWATI } \\
\text { et al. }\end{array}$ \\
\hline 18. & PPT-tool 4.066-1.1 & $\begin{array}{l}\text { Course on Landslide Disaster Risk Reduction for Local Government } \\
\text { Level Stakeholders }\end{array}$ & $\begin{array}{l}\text { Asian Disaster Preparedness } \\
\text { Centre }\end{array}$ \\
\hline 19. & PPT-tool 4.886-1.1 & Typhoon Loss Assessment System (TLAS) Taiwan Web Tool & Hsin-Chi Li et al. \\
\hline 20. & PPT-tool 4.886-1.2 & $\begin{array}{l}\text { Assessment Social Impact of debris flow disaster by Social Vulnerability } \\
\text { Index }\end{array}$ & Ko-Fei Liu et al. \\
\hline 21. & PPT-tool 4.886-1.3 & $\begin{array}{l}\text { Tutorial: Procedures for Constructing Disaster Evacuation Maps (56 } \\
\text { pages) }\end{array}$ & $\begin{array}{l}\text { Su-Chin Chen, Lien-Kuang } \\
\text { Chen }\end{array}$ \\
\hline 22. & Video-tool 3.084-2.1 & Manual for undrained dynamic-loading ring shear apparatus & Lam Huu Quang \\
\hline
\end{tabular}

as the major contribution from the global landslide community.

The following four types of landslides: Falls (falls and topples), Slides (rotational and translational), Spreads and Flows (debris flow and debris avalanches) are explained using illustrations and photo examples in Figs. 2, 3, 4 and 5.

\section{Landslide Dynamics for Risk Assessment (TXT-Tool 0.081-1.1)}

All figures and captions are copied from TXT-Tool 0.081-1.1. 
Table 4 Contents of PDF tools

\begin{tabular}{|c|c|c|c|}
\hline \multicolumn{4}{|c|}{ List of PDF Tools } \\
\hline No. & Identifier & Title & Author \\
\hline 1. & PDF-tool 1.064-1.1 & $\begin{array}{l}\text { Field guide for the identification and assessment of Landslide } \\
\text { and Erosion features and hazards affecting pipelines }\end{array}$ & $\begin{array}{l}\text { Chris Massey, Graham Hancox, Mike } \\
\text { Page }\end{array}$ \\
\hline 2. & PDF-tool 3.081-1.1 & $\begin{array}{l}\text { An integrated model simulating the initiation and motion of } \\
\text { earthquake and rain induced rapid landslides and its application } \\
\text { to the } 2006 \text { Leyte landslide }\end{array}$ & Kyoji Sassa \\
\hline 3. & PDF-tool 3.081-1.3 & $\begin{array}{l}\text { A hypothesis of the Senoumi submarine megaslide in Suruga } \\
\text { Bay in Japan based on the undrained dynamic-loading ring shear } \\
\text { tests and computer simulation }\end{array}$ & Kyoji Sassa, Bin He \\
\hline 4. & PDF-tool 3.081-1.5 & Manual for the LS-RAPID software & Kyoji Sassa, Hendy Setiawan et al. \\
\hline 5. & PDF-tool 3.081-1.6 & Manual for undrained dynamic-loading ring shear apparatus & Hendy Setiawan et al. \\
\hline 6. & PDF-tool 3.081-1.7 & $\begin{array}{l}\text { Undrained dynamic-loading ring shear apparatus and its } \\
\text { application to landslide dynamics }\end{array}$ & Kyoji Sassa et al. \\
\hline 7. & PDF-tool 3.081-1.9 & $\begin{array}{l}\text { Dynamic properties of earthquake-induced large-scale rapid } \\
\text { landslides within past landslide masses }\end{array}$ & Kyoji Sassa \\
\hline 8. & PDF-tool 4.091-1.1 & Guidelines for landslides management in India & Surya Parkash \\
\hline 9. & PDF-tool 4.091-1.2 & Training module on comprehensive landslide risk management & Surya Parkash \\
\hline 10. & PDF-tool $0.001-2.1$ & The landslide handbook: a guide to understanding landslides & Lynn Highland, Peter Bobrowsky \\
\hline 11. & PDF-tool 4.064-1.1 & $\begin{array}{l}\text { Guidelines for assessing planning policy and consent } \\
\text { requirements for landslide-prone land }\end{array}$ & Wendy Saunders and Phillip J. Glassey \\
\hline 12. & PDF-tool 4.064-1.2 & Shut happens - building hazard resilience for businesses in NZ & Resilient Organisations \\
\hline 13. & PDF-tool 4.064-1.3 & $\begin{array}{l}\text { Working from the same page - consistent messages for CDEM: } \\
\text { PART B: Hazard-specific information-landslides }\end{array}$ & $\begin{array}{l}\text { Ministry of Civil Defence and } \\
\text { Emergency Management }\end{array}$ \\
\hline 14. & PDF-tool 4.081-3.1 & $\begin{array}{l}\text { Japanese laws, codes, guideline and standard procedure } \\
\text { regarding disaster prevention and risk reduction in Japan }\end{array}$ & $\begin{array}{l}\text { Erosion and Sediment Control } \\
\text { Department, Ministry of Land, } \\
\text { Infrastructure, Transport and Tourism, } \\
\text { Japan and International Sabo Network }\end{array}$ \\
\hline 15. & PDF-tool 4.007-2-1 & Summer school guidebook & Alexander Strom \\
\hline
\end{tabular}

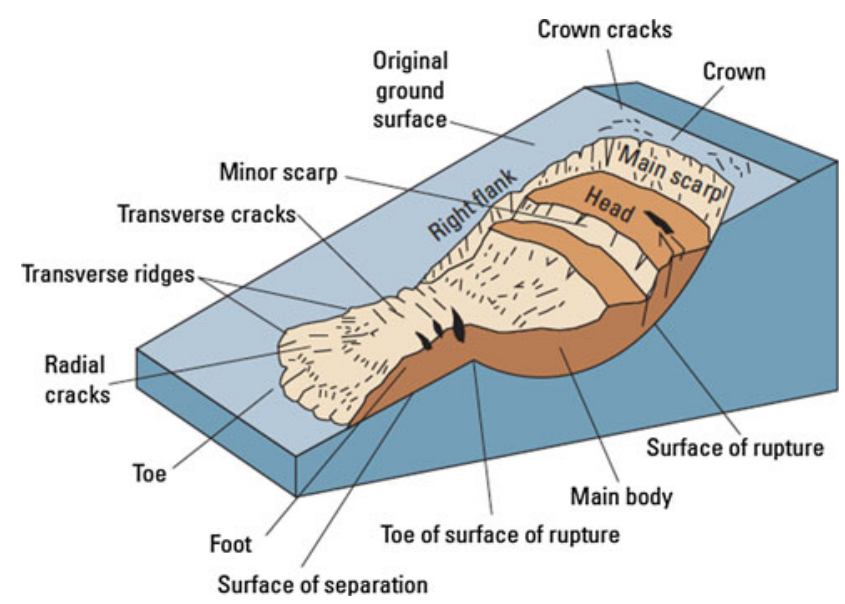

Fig. 1 This graphic illustrates commonly-used labels for the parts of a landslide. The image shows a rotational landslide that has evolved into an earthflow (modified from Varnes, 1978)
Figure 6 presents three major types of tests to measure the shear strength of soils: (1) Direct shear tests (shear box tests) in which a sample is sheared until failure in the drained condition in a shear speed control test, (2) Triaxial compression tests in which a sample is compressed until failure, either in either a drained condition or undrained condition, in either a stress control or speed control test, 3 . Ring shear test in which a sample is sheared until a residual strength is obtained after failure in the drained condition during a speed control test.

Figure 7 presents the new undrained dynamic loading ring shear test which can simulate the initiation and the motion of landslides, by loading normal and shear stress in the field, including seismic stress loading and pore-pressure increase during rainfall. The most important feature of this new apparatus is the ability of to maintain an undrained condition and the measurement of pore-water pressure changes near the sliding surface (zone). The most important 

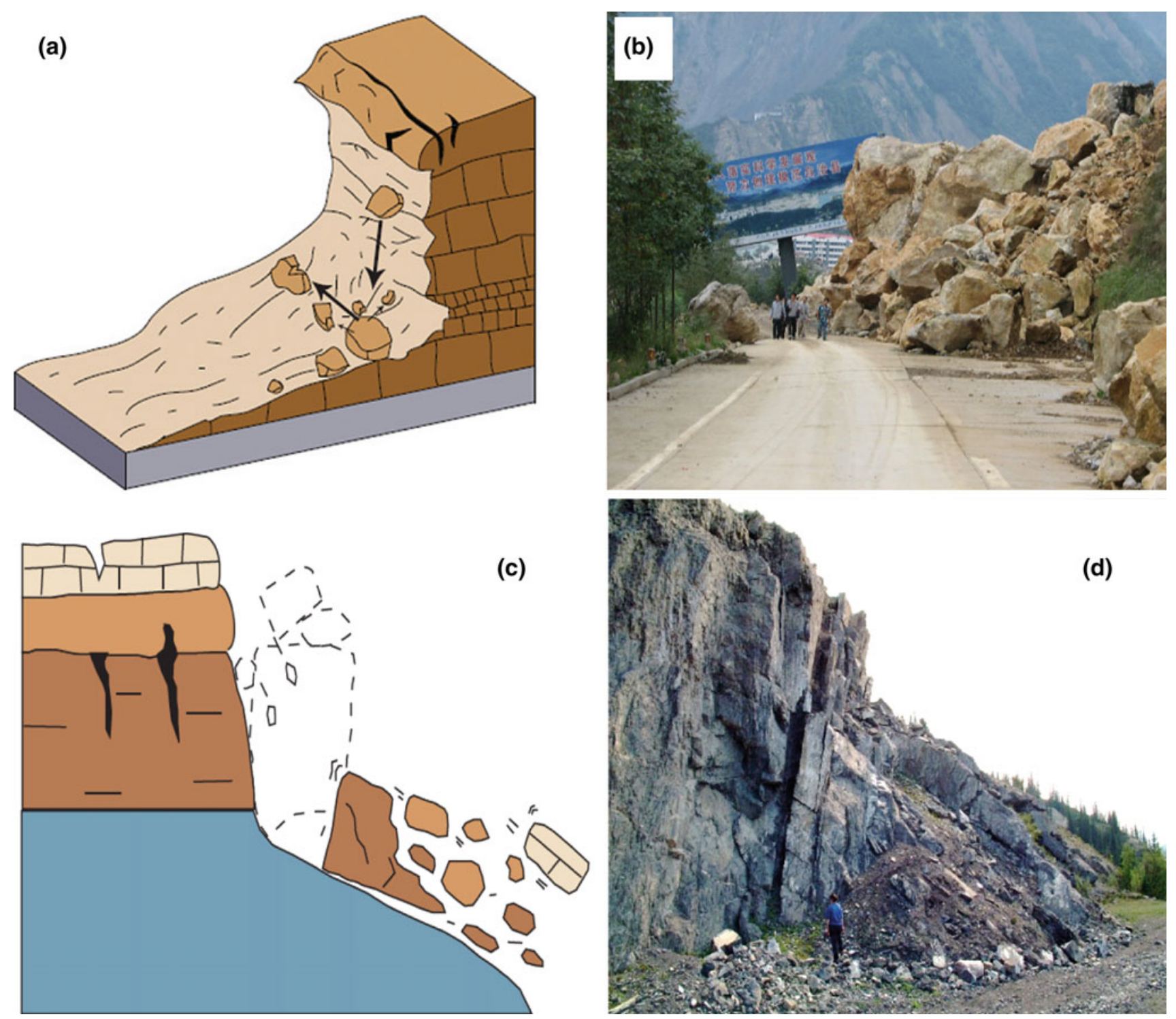

Fig. 2 Illustrations and photos of an example of Falls. a Schematic illustration of rockfall. Note that rocks may roll and bounce at potentially great distances depending on a number of factors. b A large rockfall due to the May, 2008 Wenchuan, China Earthquake. Photo by

Dave Wald, U.S. Geological Survey. c Schematic illustration of a topple. d A topple in the vicinity of Jasper National Park, British Columbia, Canada. Photo by G. Bianchi Fasani

factor for the landslide disaster risk assessment is the estimation of velocity and the travel distance, and the moving area of landslides. The velocity and hazard area of a landslide is controlled by shear resistance mobilized in the sliding surface of the landslide. The resistance is regulated by the pore water pressure generated during initiation and motion, as well as seismic shaking. The water leakage from the gap between the upper shear box and the lower shear box is prevented by a rubber edge. The contact stress of the rubber edge to the upper ring shear box is controlled to be higher than the generated pore water pressure in the servo-control system. Two sets of new apparatuses (ICL-1 and ICL-2) were donated to Croatia and Vietnam from the

Government of Japan through the SATREPS project (Science and Technology Research Partnership for Sustainable Development). The system was developed to be practical toly maintain,ed even in developing countries.

Figure 8 illustrates the great effect of pore water pressure. During rainfalls, the ground water level is increased in a soil layer on the bed rock (stable) layer of the slope. The mobilized shear resistance on the sliding surface is affected by the effective weight of the soil layer.

B illustrates a block inside a pool. A necessary horizontal force to move this block is decreased when a the water table will increases and the effective weight of the block is decreased by the buoyant force due to water. If the density of 

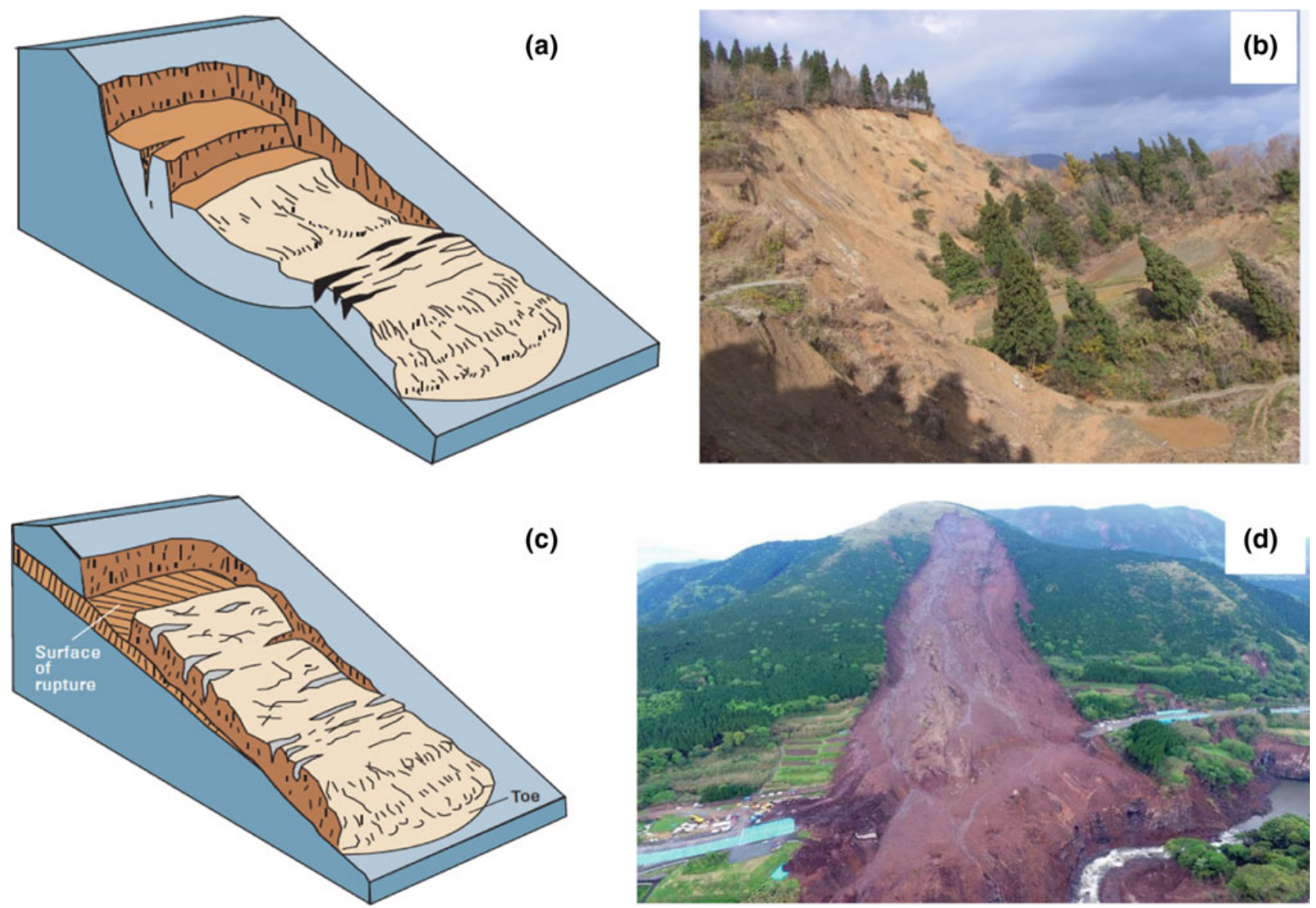

Fig. 3 Illustrations and photos of examples of slides. a Schematic of a rotational landslide. b A photo of a rotational landslide, showing the Dainichi-san landslide triggered by the October 23, 2004 Mid-Niigata Prefecture earthquake (Sassa 2005). c Schematic of a translational
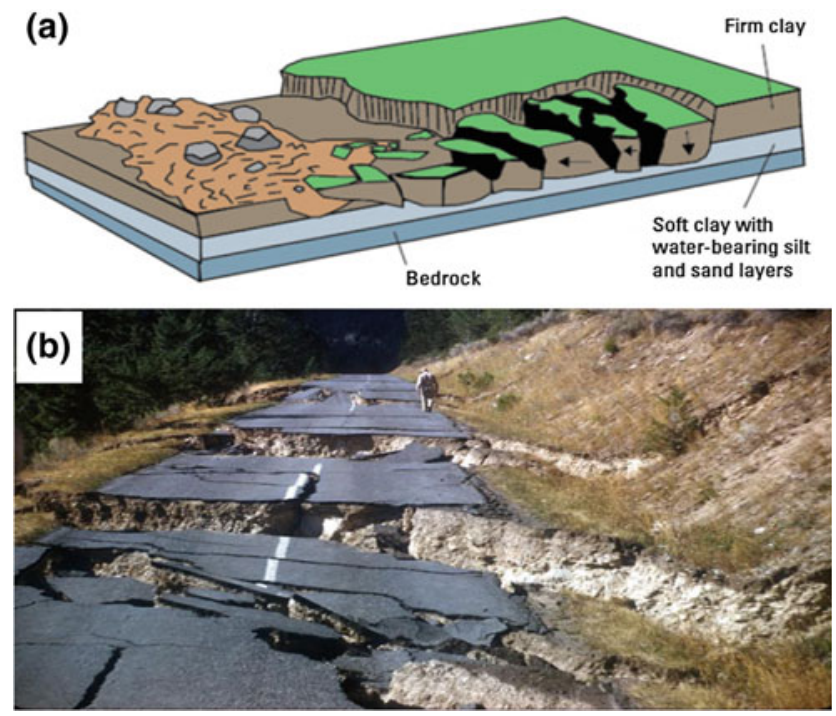

Fig. 4 Illustration and photo of an example of a spread. a Schematic of a lateral spread. b Lateral spreads at Hebgen Lake near West Yellowstone, Montana (USA), due to the effects of the Magnitude 7.3 Hebgen Lake earthquake, on August 18, 1959. Photo by R.B. Colton, U.S. Geological Survey (parallel to slope) landslide. d The Minami-Aso Landslide shows a translational landslide in a steep slope. The landslide was triggered by the Kumamoto Earthquake of 2016 in Japan (Dang et al. 2016). Photo taken from UAV by Khang Dang and Kyoji Sassa

the block is similar to water, the block is almost floated floating in the water, and the necessary horizontal force to move this block is zero. Namely, the shear resistance between the block and the bottom of this pool is zero. The most difficult part is to know the function of pore water pressure.

Figure 9 illustrates the landslide initiation mechanism. Two figures show the normal stress and the shear stress relationships working on the sliding surface of a potential landslide. The left top shows a soil column within a slope. The mass of the soil column imparts a load (mass and gravity - $\mathrm{mg}$ ) to the sliding surface. The shear stress component is $\mathrm{mg} \cdot \sin \theta$ and the normal stress component is $\mathrm{mg} \cdot \cos \theta$. From this relationship, the initial stress is expressed as point $I$ in this normal stress-shear stress chart, assuming no pore water pressure. When the ground water table is increased during rain, pore water pressure (u) is increased. In this case, the effective normal stress (normal stress minus pore water pressure) is decreased. Namely, the stress point in this chart will move to the left direction by $\mathrm{u}$ from the point $\mathrm{I}$. When the stress point reaches the failure 

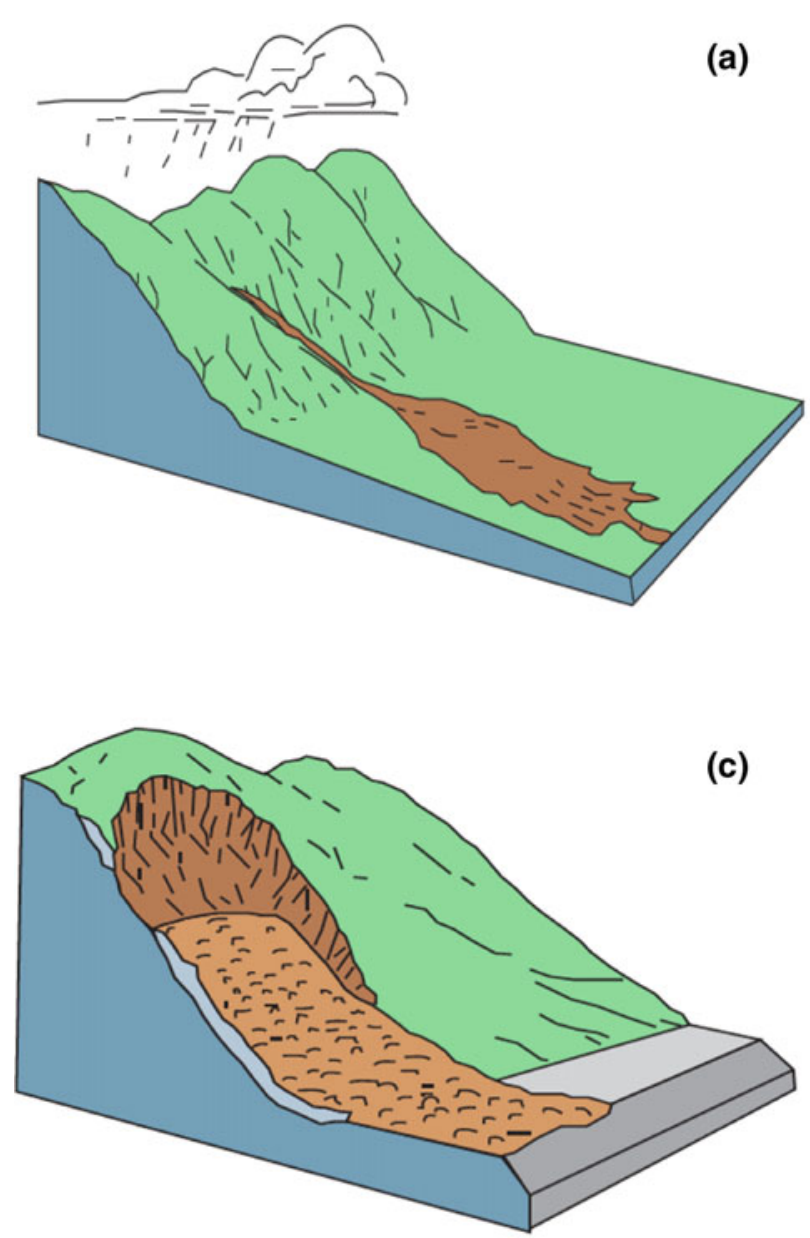

Fig. 5 Illustrations and photos of examples of flows Debris flows and debris avalanches are introduced as a major group of flow types of landslides. a Schematic illustration of a debris flow. b A photo of the July 20, 2003 debri flow which occurred in Minamata City, Kyushu

line of this soil, the soil will fail. This is the initiation of landslide by the mechanism of rainfall.

The right figure illustrates the initiation of landslide by pore water pressure plus earthquake loading. In the case of slope layer that includes a certain height of ground water table, as shown in Fig. 8, the initial stress before the earthquake is located at A in Fig. 9. When an earthquake strikes this area, seismic stress is loaded. The direction and the stress level will differ depending on the earthquake acceleration and its direction, but the stress point moves from A to somewhere. If the stress point reaches the failure line, the soil layer will fail and a landslide is initiated. This is the mechanism of an earthquake-induced landslide. Whether the landslide will be initiated or not can be simulated using the undrained ring shear apparatus by loading the seismic stress (an example test result is shown in Fig. 17).

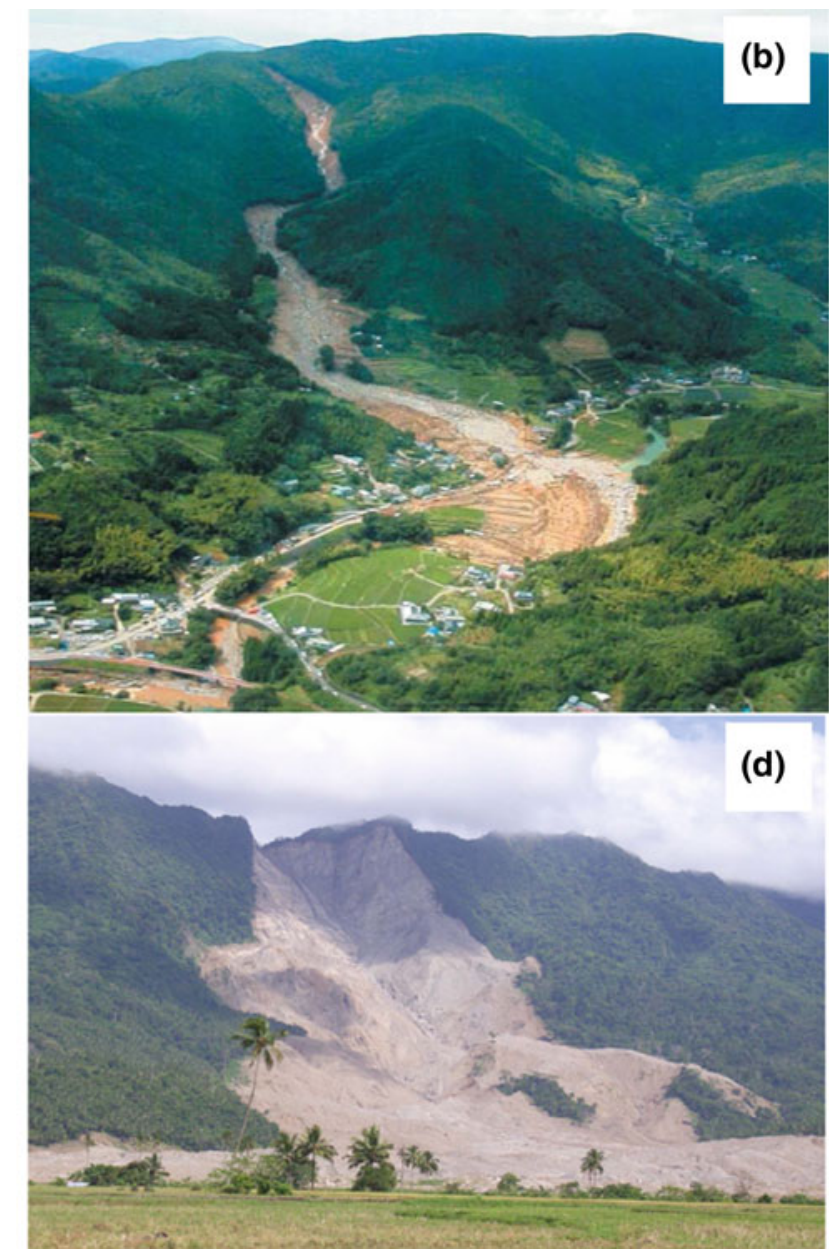

Island, Japan, resulting in 14 deaths and 15 houses destroyed (Sassa et al. 2004). c Schematic of a debris avalanche. d A debris avalanche that buried a village in Guinsaugon, Southern Leyte, Philippines, in February, 2006 (Photo by University of Tokyo Geotechnical Team)

Figure 10 illustrates two cases of the undrained dynamic loading ring shear tests for the initiation of a landslide and the movement of a the landslide. A sample will be taken from the potential shear zone or the soil layer or a layer which is estimated to have the same mechanical properties. The ring shear test will be conducted to determine whether a landslide will be initiated or not as shown in Fig. 9. The initiated landslide mass will move to the lower slope or onto the alluvial deposit, as shown in the right figure of Fig. 10. The shear surface will be formed within the deposit. A sample will be taken from the deposit on which the landslide mass now loadsrests on. A dynamic stress simulating the undrained loading by the moving landslide mass is given applied to the sample in the ring shear testing. The stress necessary stress to shearing the deposit and the generated pore water pressure and mobilized shear resistance 
Fig. 6 Major three types of shear test to measure the shear strength of soils. $A$ and $B$ (Direct shear and Triaxial compression tests) are to measure the shear strength at failure. $C$ (Ring shear test) is to measure the residual shear strength after failure
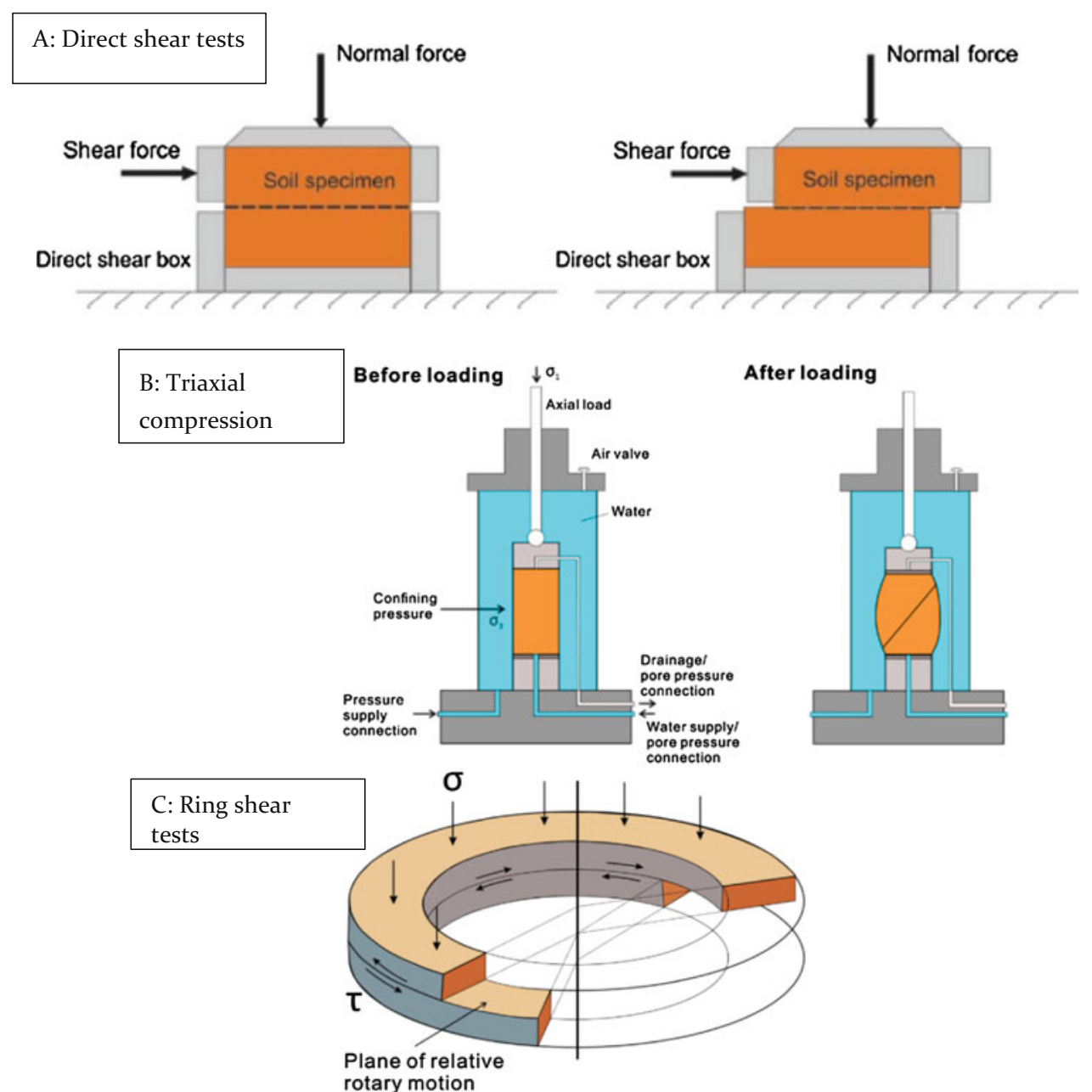

rotary motion

during loading and motion will be measured. Normally two tests are necessary to assess the initiation of landslide and the motion of landslides.

Figure 11 shows the setup (Nos. 1-6) of the undrained ring shear apparatus of ICL-2. Within this photo:

No. 1 is the computer and its two monitors (one for the test control system and one for the recording system).

No. 2 is the control unit, including the amplifiers for various monitoring sensors and the four servo-control amplifiers (Normal stress, shear stress, gap control and pore water pressures).

No. 3 is the main body of the undrained ring shear apparatus, including loading shear stress and speed control motor and gap control motor, normal stress loading system, the vertical and shear displacement measuring sensors, and pore pressure sensors (shown in Fig. 7).

No. 4 is the electricity supply and control system box.

No. 5 is pore pressure supply and control system.
No. 6 is the de-aired water supply system with a vacuum pump, vibration control system, and a vacuum tank to produce the sample fully saturated by de-aired water.

Figure 12 illustrates the concepts of the integrated landslide simulation model (LS-RAPID). A soil column is taken from the landslide mass, and all forces (self-weigh of soil column, the seismic forces, the lateral pressure, shear resistance on the bottom and the normal stress on the bottom) acting on this column are summed. The sum of force should accelerate the soil mass of the column. The change of pore water pressure and the resulting shear resistance on the bottom during the seismic loading, dynamic loading and shearing are obtained from testing using the undrained dynamic loading ring shear apparatus. The development of the undrained dynamic loading ring shear test has enabled the development of an integrated landslide simulation model applicable from the initiation of the motion until the termination of motion. Examples of the simulation results are shown in Figs. 13, 14 and 15. 


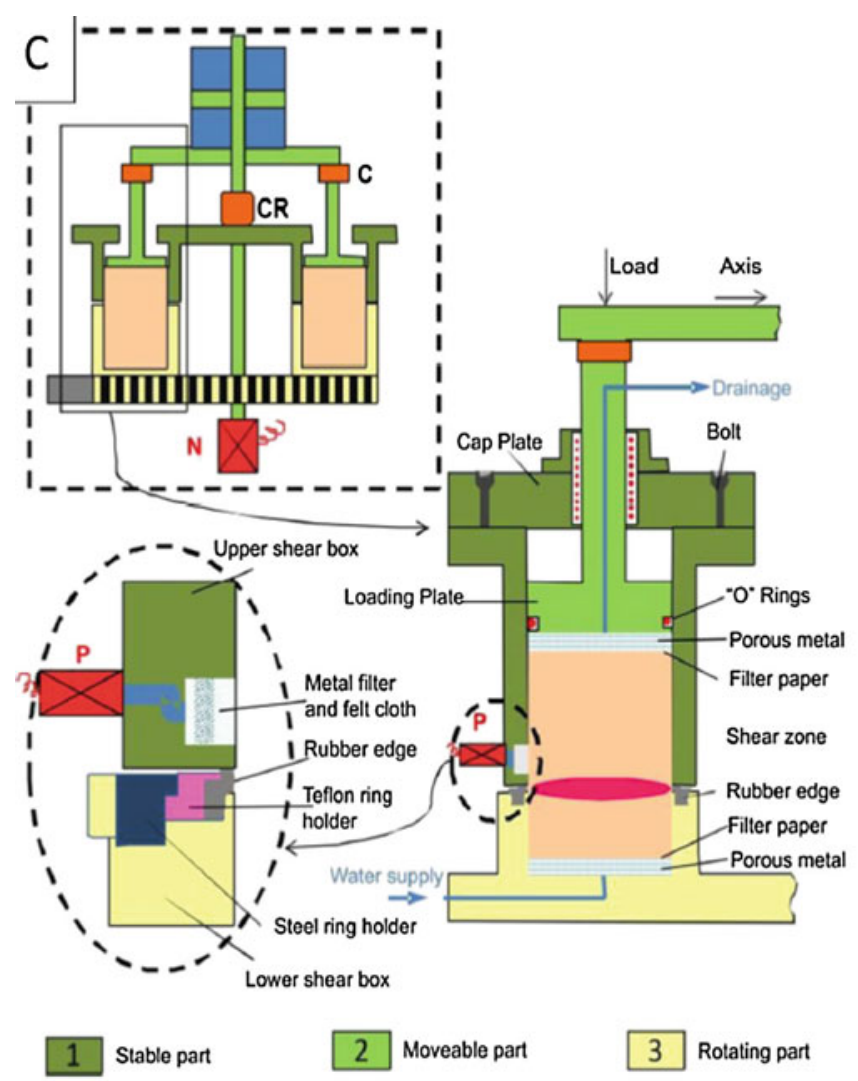

Schematic figure of the undrained dynamic-loading ring shear apparatus

Fig. 7 An undrained dynamic-loading ring shear apparatus. The left figure presents the schematic figure of the latest version of undrained dynamic-loading ring shear apparatus (Sassa et al. 2016). The right photo shows the shear box of the apparatus. $A$ Shear box; $B$ Normal stress loading piston; $C$ A pair of two shear stress sensors; $D$ Loading

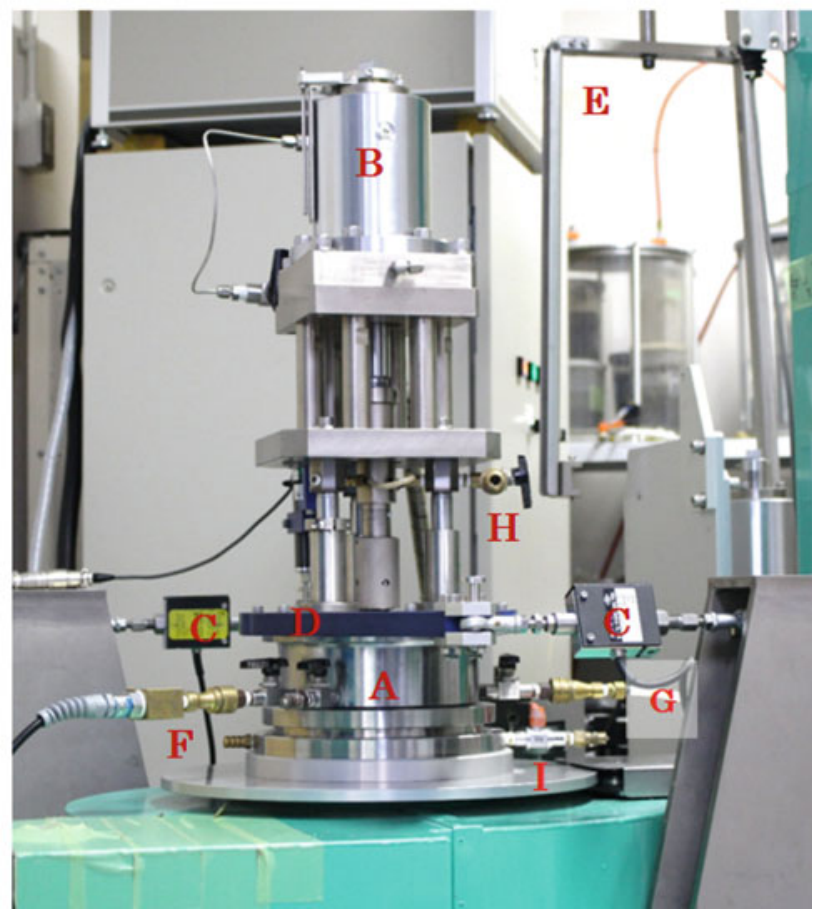

Photo of shear box and normal stress loading piston and shear stress sensor

cap; $E$ Hanging frame to lift the loading cap; $F$ Pore-pressure sensor; $G$ Connection to the pore-pressure control system; $H$ One-touch plug for the water drainage from the shear box; $I$ One-touch plug for the de-aired water supply from the bottom of the shear box
Fig. 8 Illustration of the initiation mechanisms of shallow and deep landslides due to rainfall

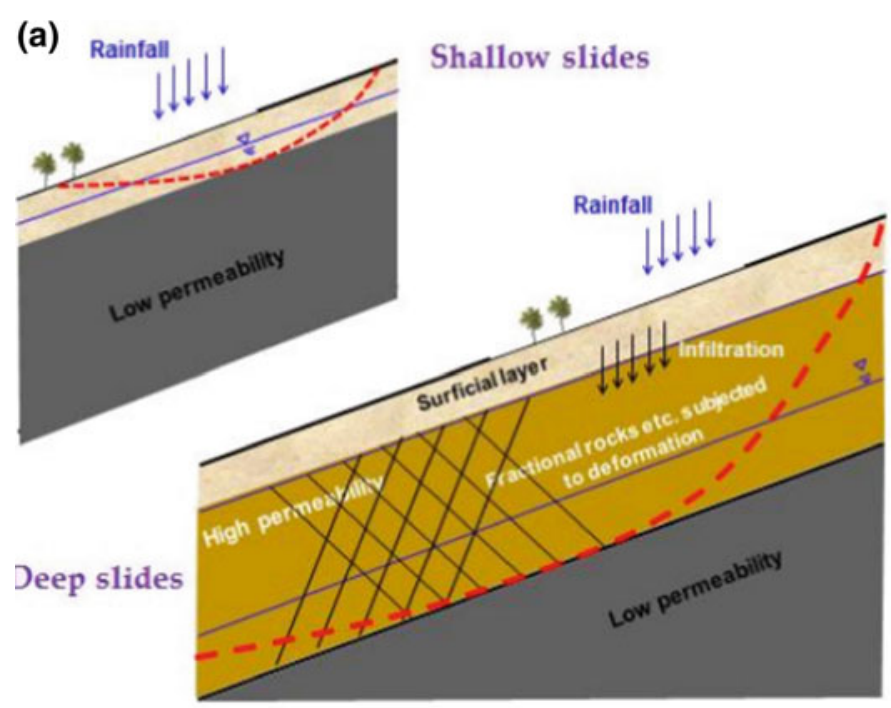

(b)
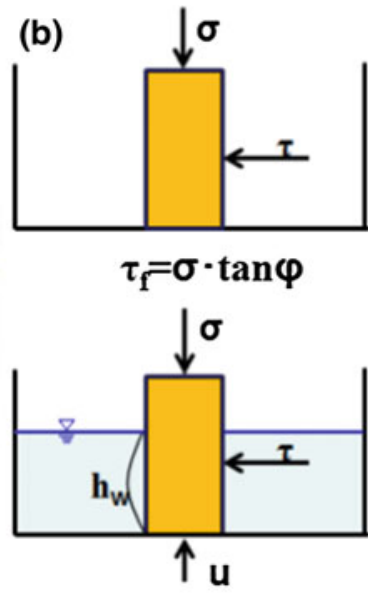

$\tau_{\mathrm{f}}=(\sigma-\mathrm{u}) \cdot \tan \varphi$ $\mathbf{u}=\mathbf{h}_{\mathrm{w}} \cdot \mathbf{Y}_{\mathrm{w}}$ 

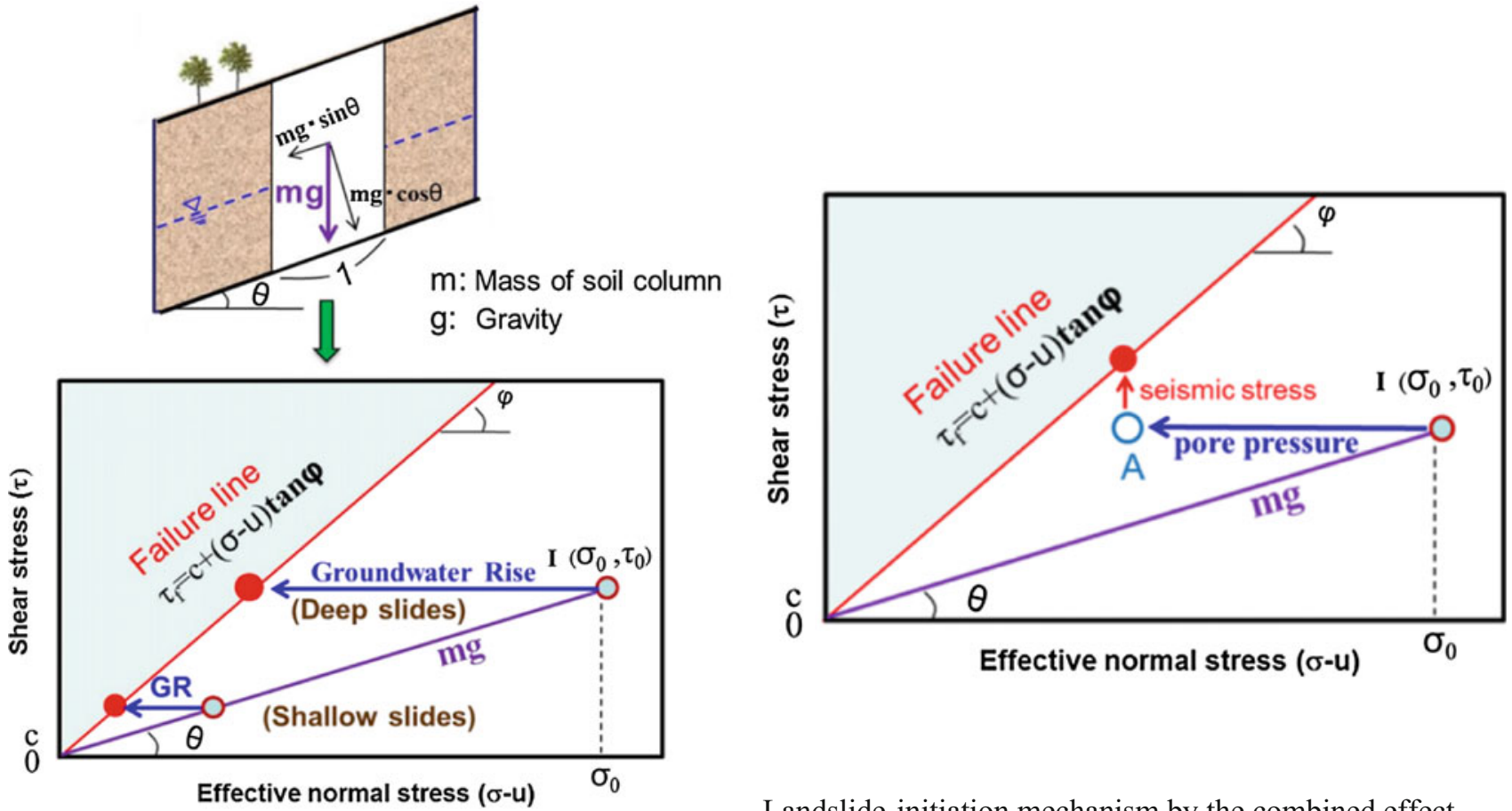

$\sigma_{0}=\mathrm{m} . \mathrm{g} \cdot \cos \theta, \tau_{0}=\mathrm{m} \cdot \mathrm{g} \cdot \sin \theta$

Landslide-initiation mechanism by the combined effect of earthquake and pore pressure rise

Landslide-initiation mechanism due to groundwater rise / pore-water pressure rise

Fig. 9 Illustration of the mechanism to trigger failure within a slope by the triggering factors of rain (left) and the pore pressure plus earthquakes (right)

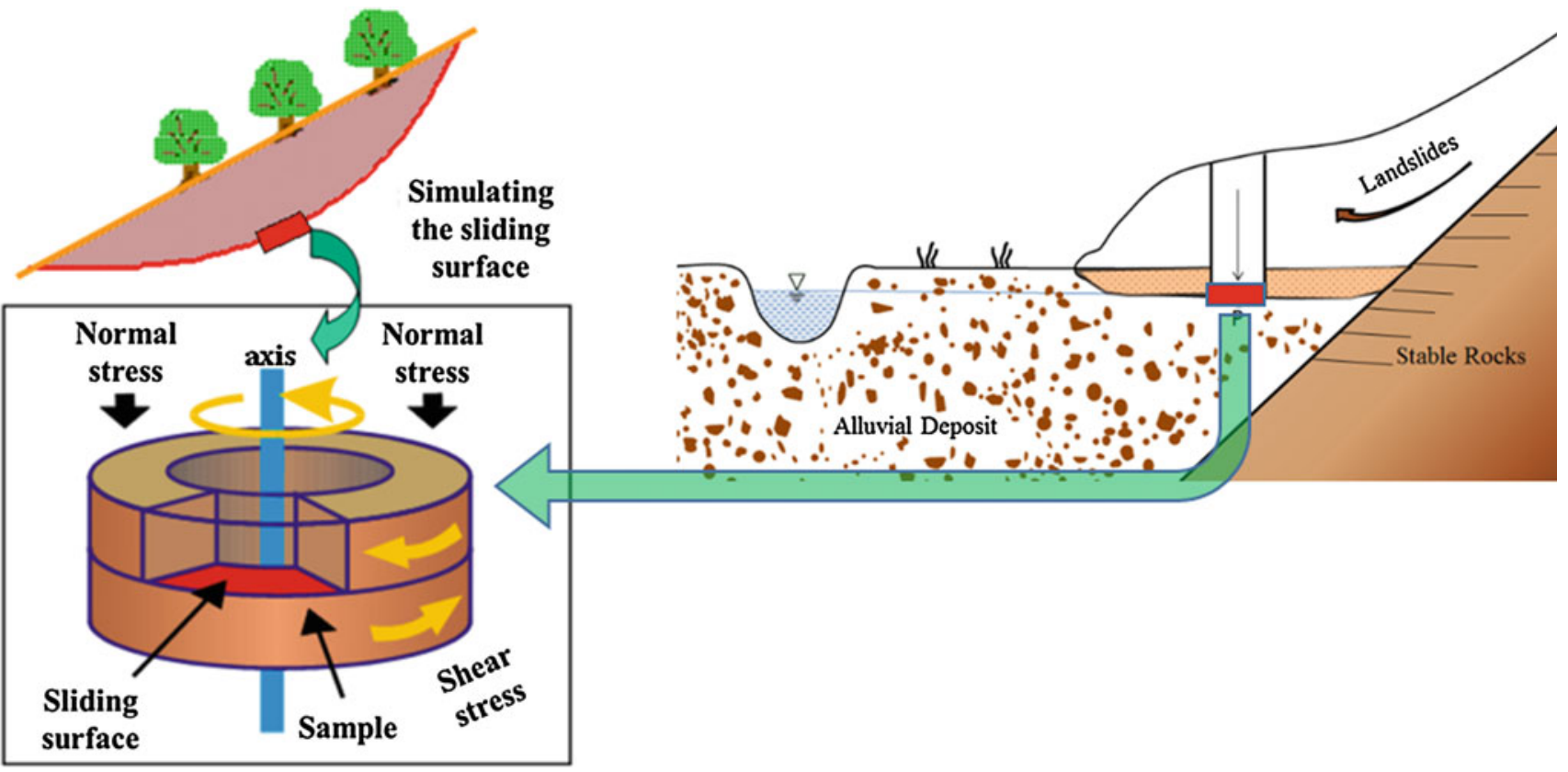

Fig. 10 Schematic figure of concept of an undrained dynamic-loading ring-shear apparatus 
Fig. 11 Photo showing the setup of the ICL-2 apparatus
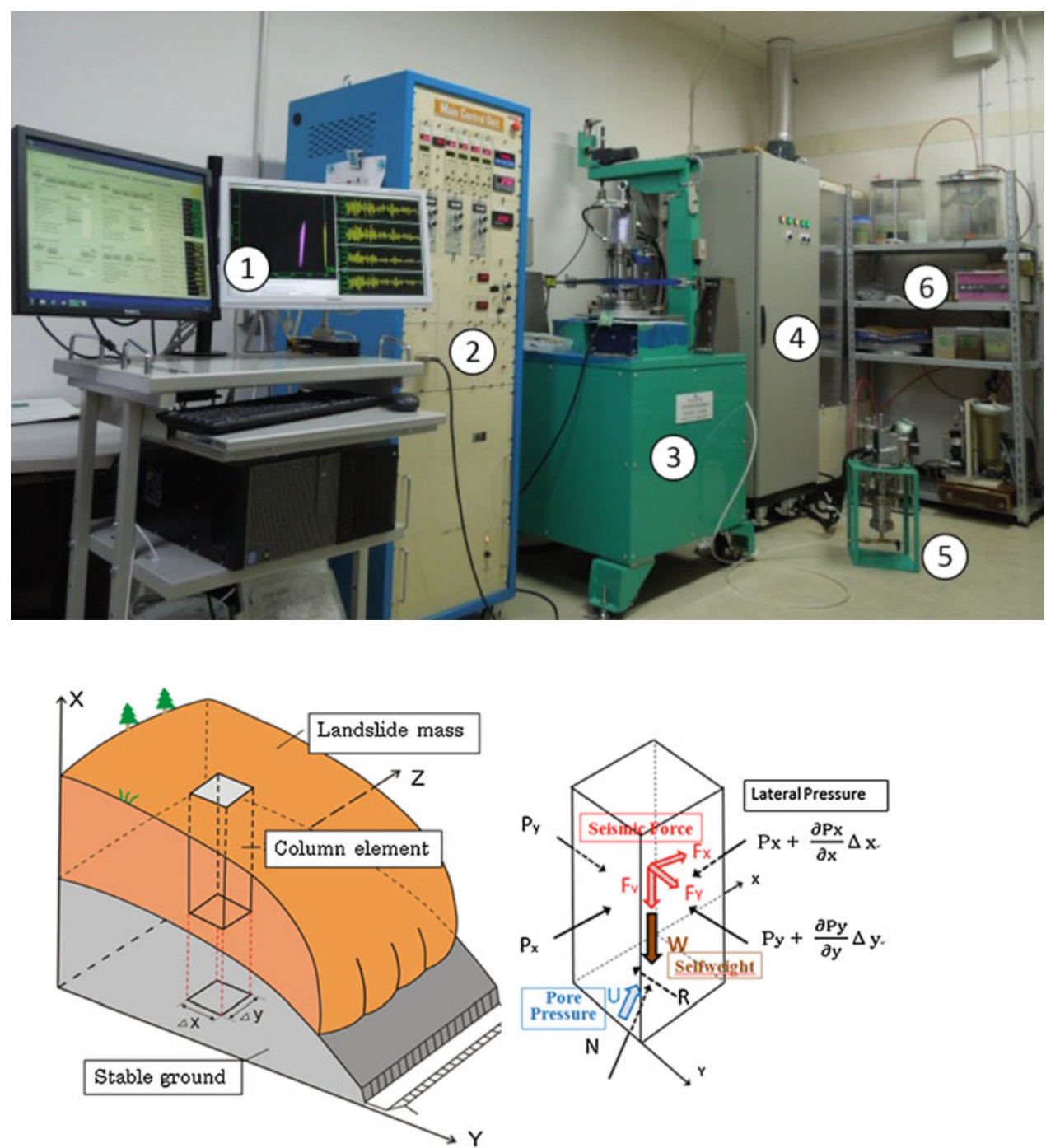

The landslide mass (m) will be accelerated by an acceleration (a) from the sum of all forces acting on the soil column.

Driving force $=($ self-weight + seismic forces $)+$ lateral pressure + shear resistance

$$
a m=(W+F v+F x+F y)+\left(\frac{\partial P_{x}}{\partial x} \Delta x+\frac{\partial P_{y}}{\partial y} \Delta y\right)+R
$$

Figures 13, 14 and 15 are show the application of LS-RAPID (Fig. 12) using the test results of the from an undrained dynamic-loading ring shear apparatus (Figs. 8 and 11). Figure 13 is shows the application of the model to the Leyte landslide in Guinsaugon in the southern Leyte, Philippines in February 2006 (introduced in the bottom of Fig. 5). The landslide was triggered by a small nearby earthquake after a long period of rainfall (Sassa et al. 2010). Figure 13 and its caption explains the simulation result in the time series figure. For the initial two figures of A and B, the loaded initial pore water ratio due to rain and the loaded seismic stress calculated from the seismic record are shown.

Figure 14 is a photo of the Yagi and Midorii area of Hiroshima city, Japan (Doan et al. 2016). Both areas and the surrounding areas were struck by debris flows which came from the many of shallow landslides from the top of slopes during a local heavy rain. In all 74 people were killed in the urbanized residential areas. Figure 15 shows the result of the LS-RAPID computer simulation using the landslide dynamics parameters obtained from the testing using the 


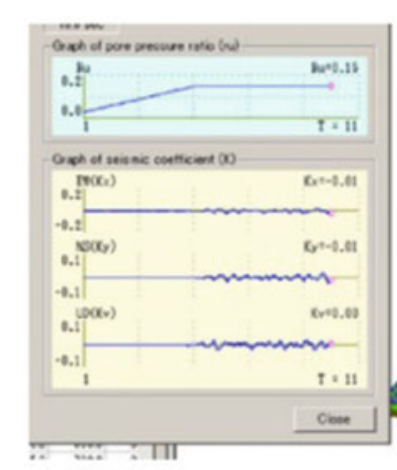

(a)

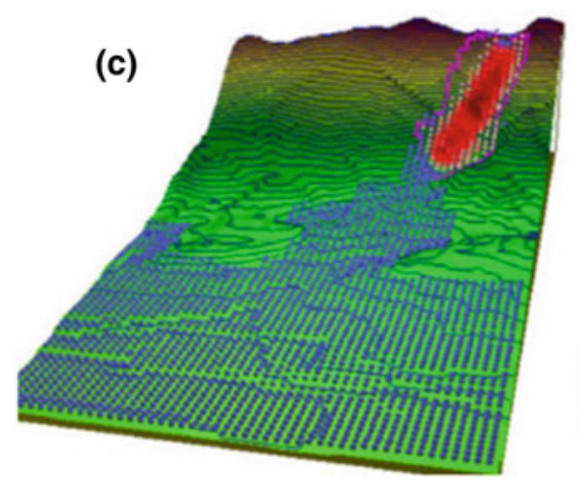

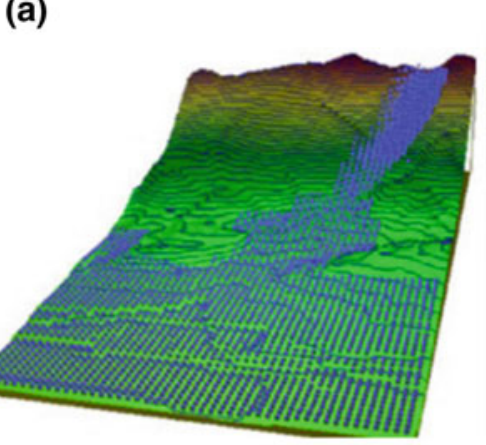

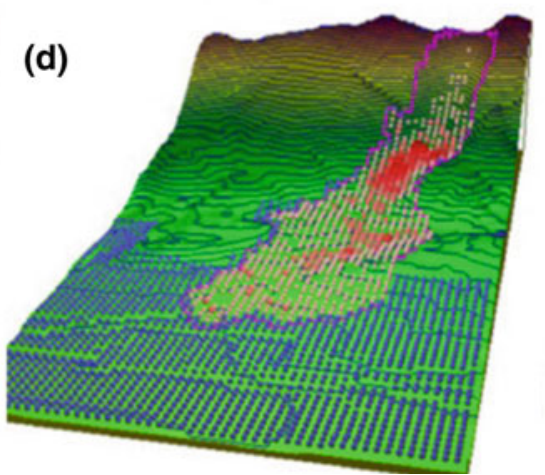

(b)
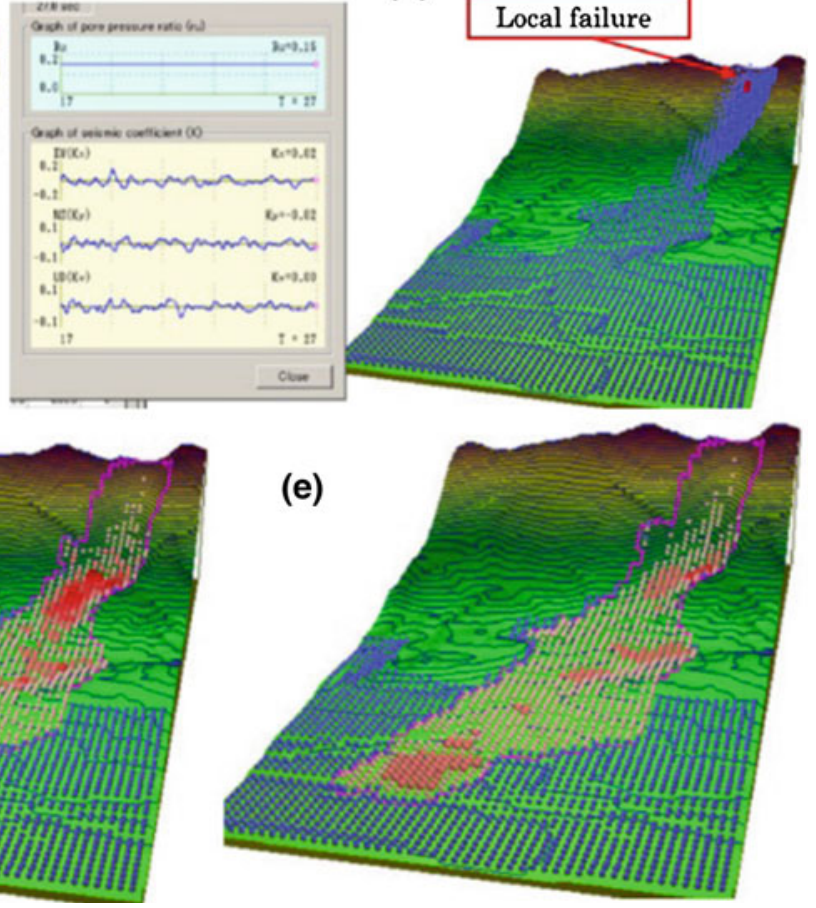

Fig. 13 Simulation results of the Leyte landslide. $A r_{\mathrm{u}}$ rises to 0.15 and the earthquake will start, but there is no motion. $B$ Continued earthquake loading triggers a local failure, as shown by the red color mesh, $C$ An entire landslide block is formed and moving, $D$ The top of landslide mass moves onto alluvial deposits. $E$ Deposition. Mesh size is $40 \mathrm{~m}$; the area is $1960 \times 3760 \mathrm{~m}$; contour interval is $20 \mathrm{~m}$; there is $3 \mathrm{~m}$ of unstable deposits on the alluvial deposit area (blue balls)
Fig. 14 Photo of the Yagi-area and Midorii in the 2014

Hiroshima landslide-debris flow disaster

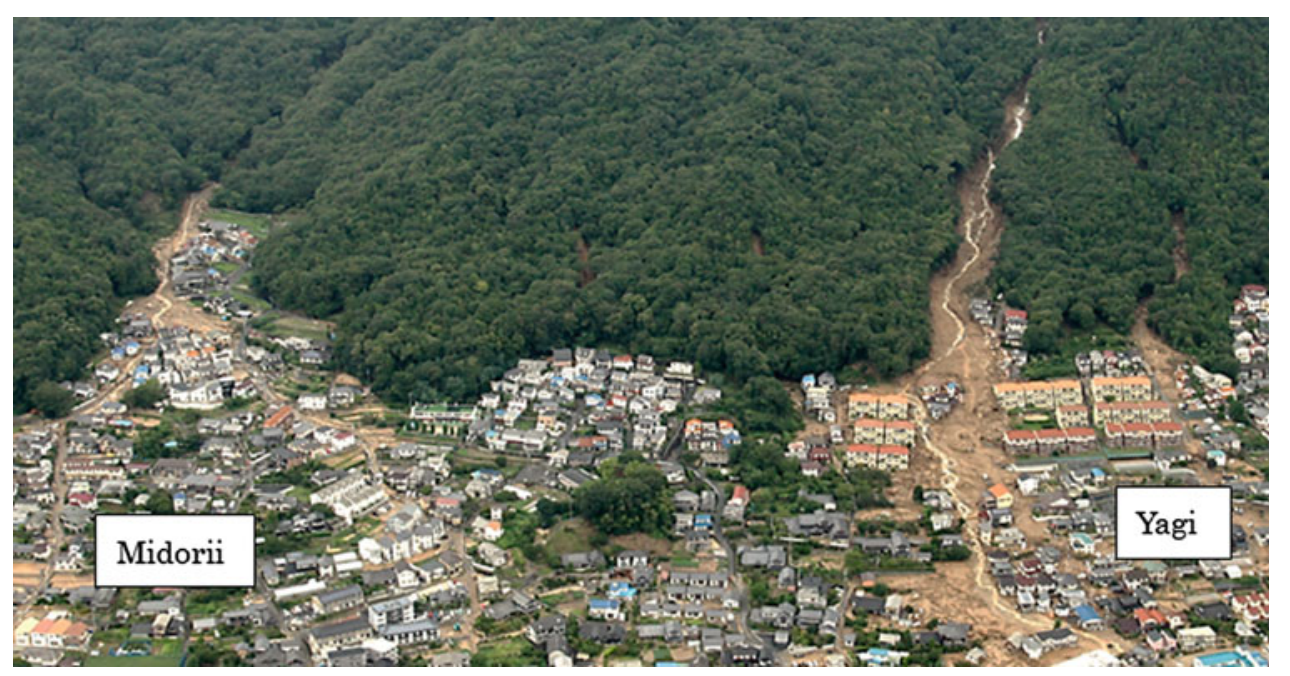

undrained dynamic-loading ring shear apparatus. For the triggering factors, the 10-minute rainfall record was used. The initiation and the motion of landslides and the landslide hazard areas are reasonably reproduced by this simulation.

Figures 16, 17, and 18 present a study of the 1792 Unzen Mayuyama landslide using undrained ring shear testing and the integrated computer simulation. Figure 16 shows the Google view of the landslide. The urban area is Shimabara city and the sea is the Ariake Sea on Kyushu island of Japan. The mountain is a part of Unzen volcano. This 1792 Unzen Mayuyama landslide-and-tsunami-induced disaster is both the largest landslide disaster and also the largest volcanic 


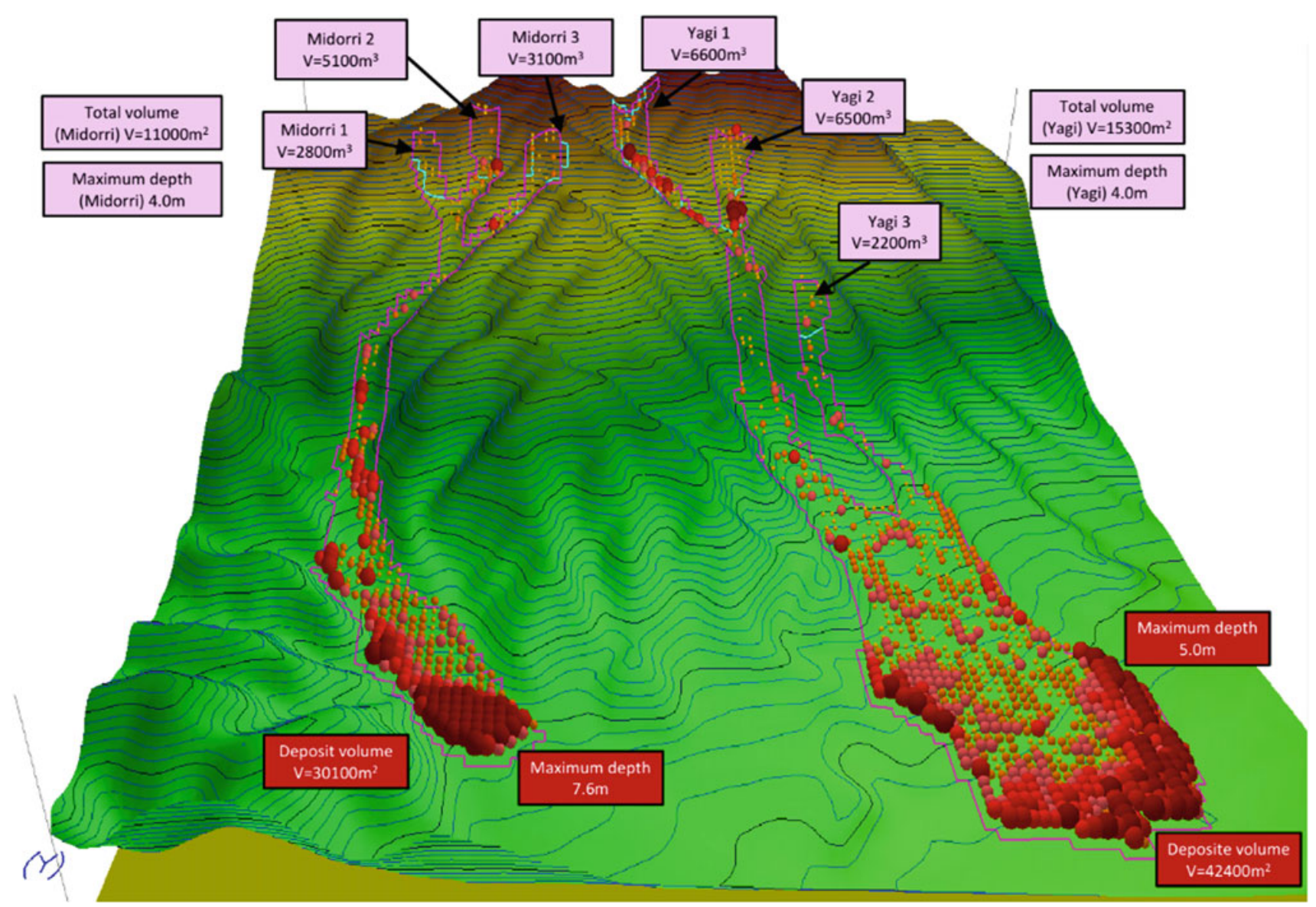

Fig. 15 Result of LS-RAPID simulation (Sassa et al. 2014)

Fig. 16 Overview of the 1792 Unzen-Mayuyama landslide

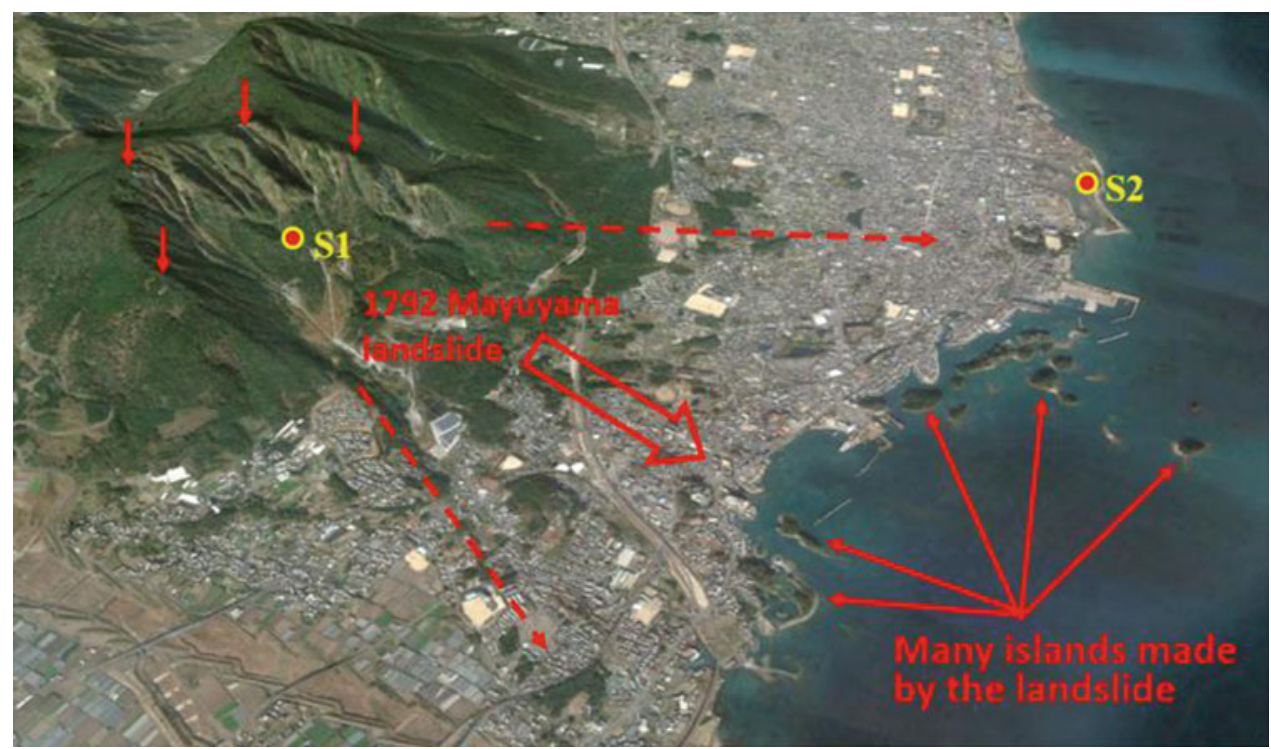




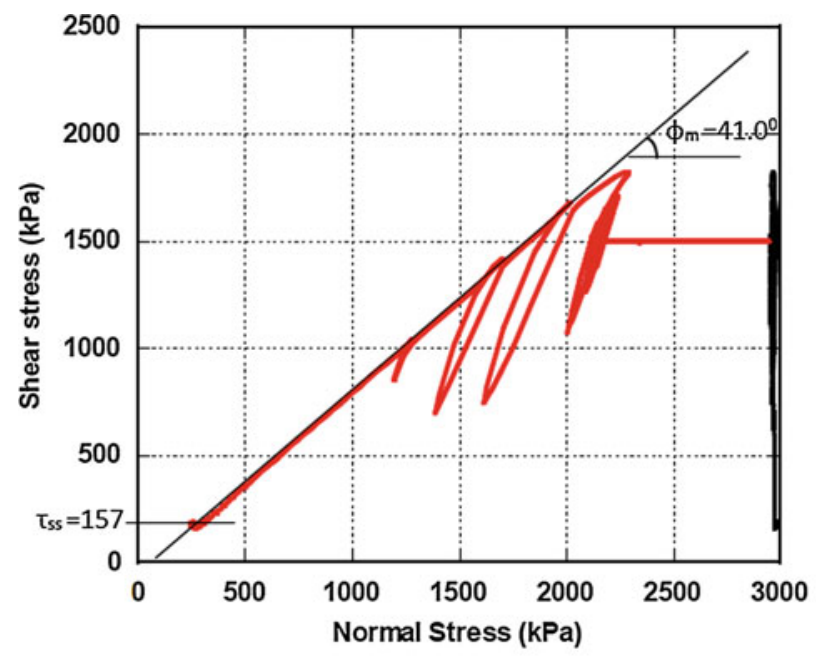

(a) Stress path

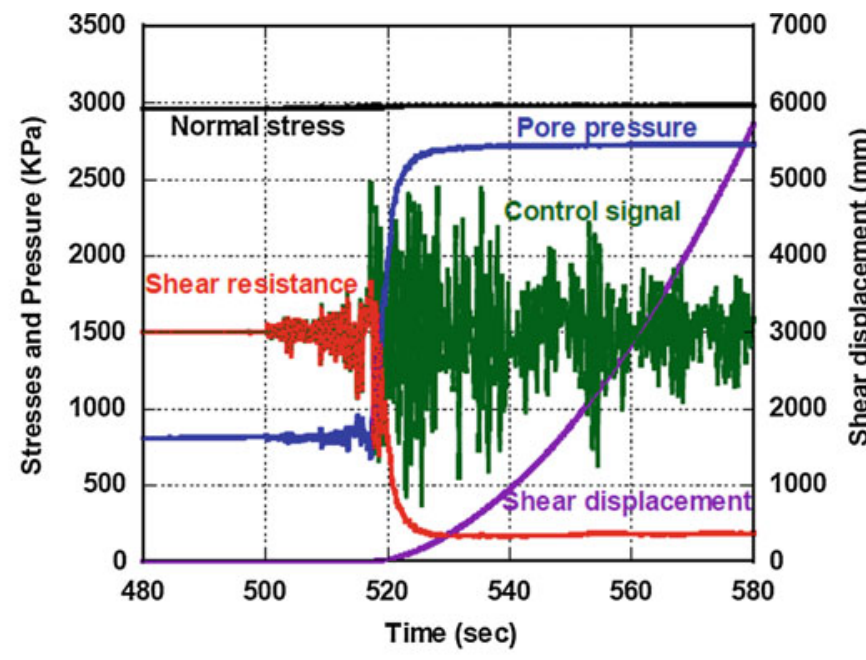

(b) Time series data

Fig. 17 Undrained seismic loading test on Sample $1(\mathrm{~S} 1) . \mathrm{B}_{\mathrm{D}}=0.94$, Seismic wave: 2008 Iwata-Miyagi Earthquake record, 5 times slower speed

disaster in Japan, and also one of greatest tsunami disasters in Japan. The landslide mass entered into the Ariake Sea. Currently there are still some islands which are parts of the landslide mass deposited in the Ariake Sea. S1 is the sampling point to study landslide initiation behavior and S2 is the sampling point to study the motion of the landslide. All the area of the moving landslide mass area is now covered by heavily developed urban building. A sample was taken from the outside of the landslide moving area. Figure 17 is an example of the undrained ring shear testing, which involved (1) loading the initial shear stress and the normal stress, (2) loading pore water pressure before the earthquake, (3) loading the seismic stress using the seismic acceleration record of the 2008 Iwate-Miyagi Earthquake, which triggered a large-scale landslide (67 million cubic meters) (Miyagi et al. 2010). The earthquake was not recorded in 1792, but the acceleration was estimated based on detailed investigation of the damage to the houses and the tomb stones in Shimabara city. The test results indicate a steady-state shear resistance of $157 \mathrm{kPa}$ and a friction angle during motion of $41^{\circ}$. Pore water pressure is built up during seismic loading and the pressure was very much increased in the progress of shearing.

Figure 18 is the simulation result of this landslide from its initiation to the motion into the sea. The initial landslide started from the middle of the source area $(17 \mathrm{~s})$ and the progressive failure expanded to the top of the landslide source area (26 s) and the total mass moved into the sea (64 s) and stopped after $226 \mathrm{~s}$. The length of the deposit area from the simulation is rather close to the area determined by field investigation by the Unzen Restoration Office.

Figures 19, 20, and 21 present the most advanced study of the landslide-induced tsunami, which was published online (April 2016) and in print (Sassa et al., Landslides Vol. 13, No. 6, 2016). Figure 19 presents the historical record of the landslide-induced tsunami disaster in the 1792 Unzen Mayuyama landslide and tsunami. In this disaster, 15,153 people were killed.

The central disaster is the concept of the landslide-induced-tsunami simulation model (LS-Tsunami). The basic concept of this model is that the landslide-induced tsunami will be simulated using the well-established and widely used model (Intergovernmental Oceanographic Commission (IOC) (1997). The basic equation is shown below in Fig. 20. As the triggering factor of the tsunami, the landslide simulation results of LS-RAPID are used. Two steps are completely separated. Interactive shear forces between the landslide mass and the water is neglected. It is assumed that the vertical uplift of the sea floor by the moving landslide mass lifts the water mass above the landslide mass vertically. Figure 21 is the result of the landslide simulation, landslide-induced tsunami simulation, and the 

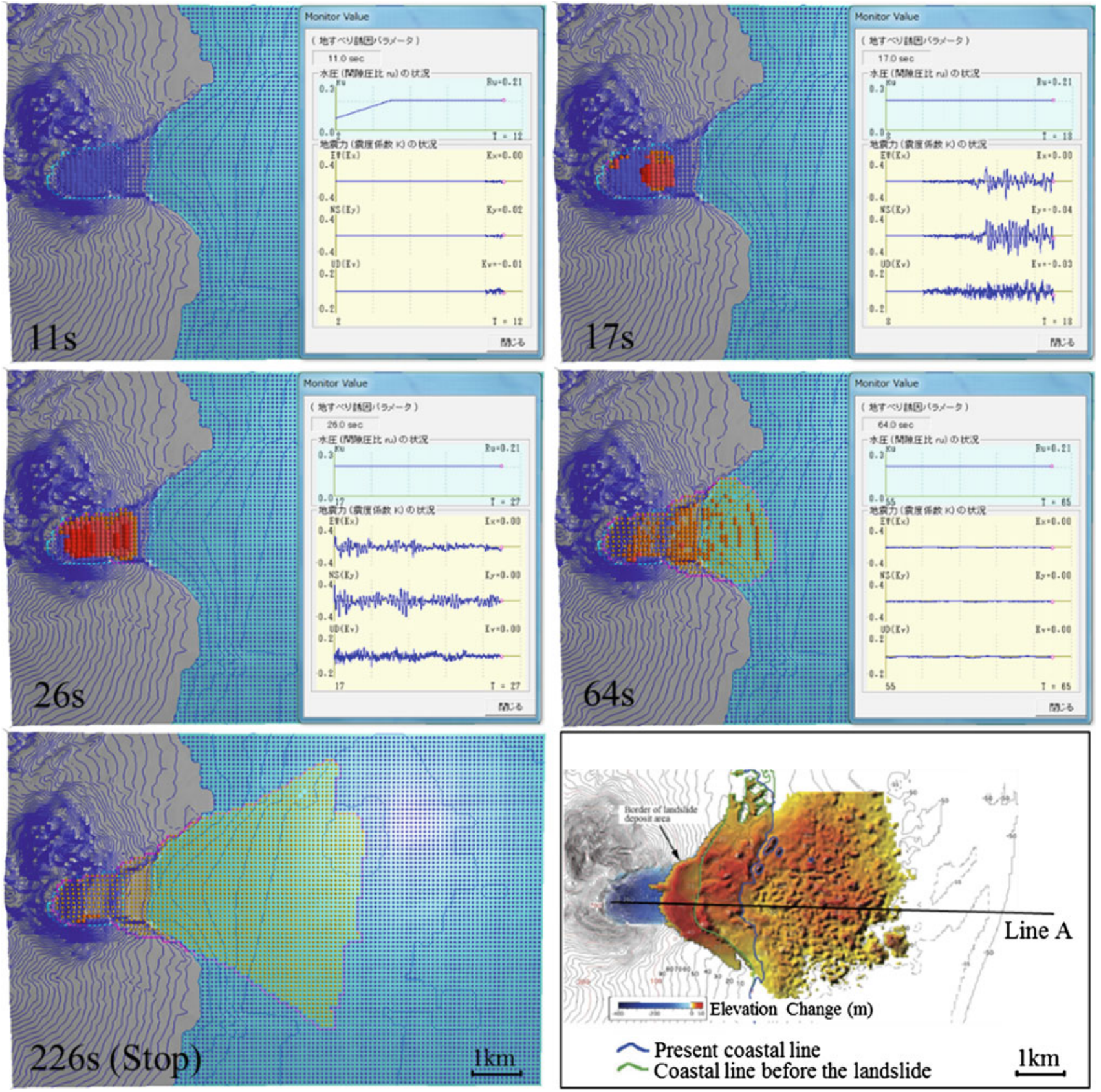

Fig. 18 LS-RAPID simulation result of the 1792 Unzen-Mayuyama landslide

tsunami motion over the sea, including reflection from the opposite shore. The first figure at $0 \mathrm{~m} 20 \mathrm{~s}$ shows the initiation of landslide. The second figure at $0 \mathrm{~m} 35 \mathrm{~s}$ shows the landslide mass reaching the coast, the third figure at $1 \mathrm{~m}$ $25 \mathrm{~s}$ shows the tsunami wave induced by the landslide mass, the fourth figure and the fifth figures at $5 \mathrm{~m} 55 \mathrm{~s}$ and $10 \mathrm{~m}$
$45 \mathrm{~s}$ show the expansion of the tsunami wave. The final two figures present the reflected wave from the opposite bank (Kumamoto Prefecture) attached the Shimabara Peninsula again. The red color tsunami wave is more than $5 \mathrm{~m}$ above sea level and the blue color tsunami wave is more than $5 \mathrm{~m}$ below sea level. The detailed tsunami height records at 5 


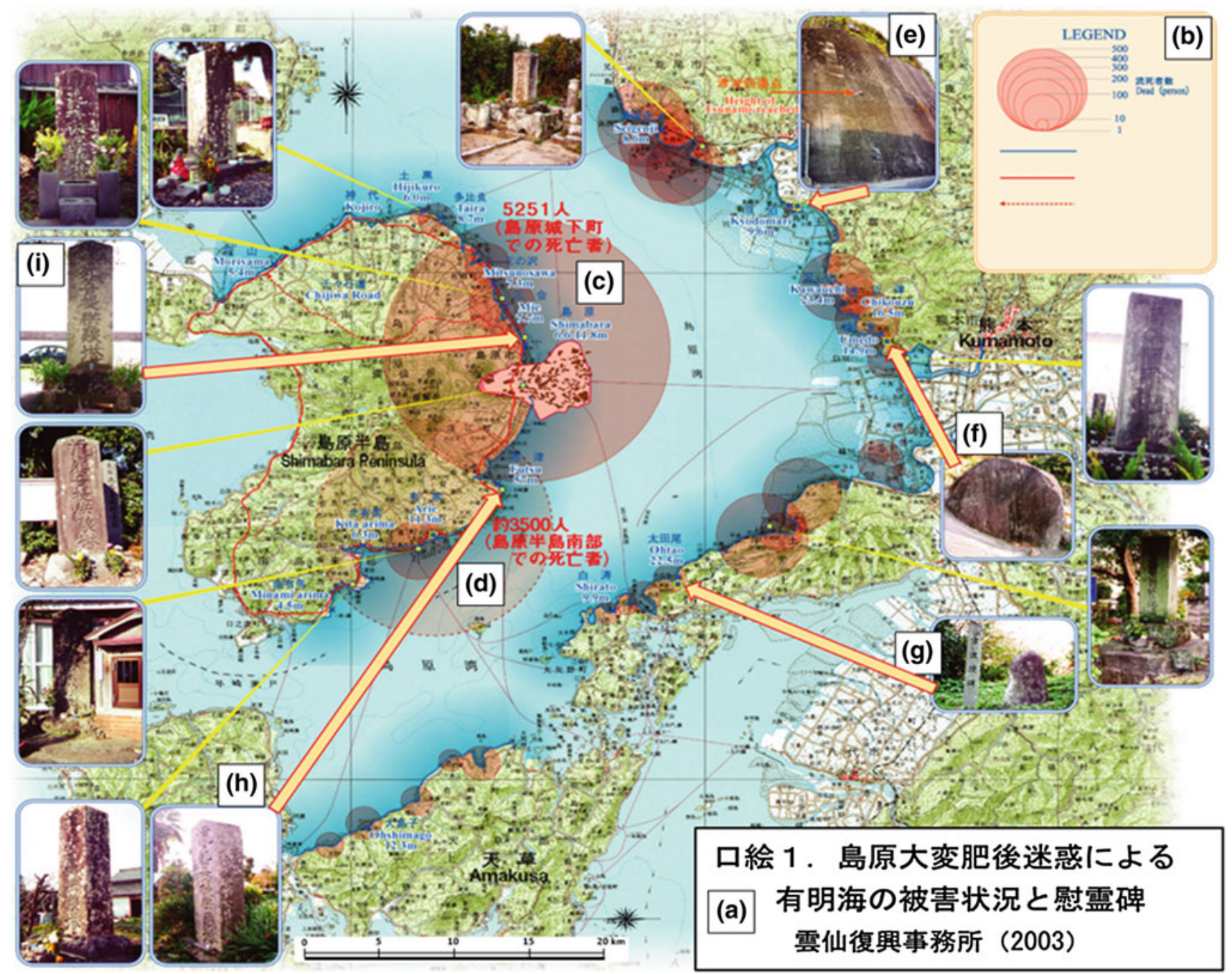

Fig. 19 Records of the Unzen landslide-and-tsunami disaster (by Unzen Restauration Office 2003). The total number of deaths is 15,153 persons. The size of circles is proportional to the number of human fatalities in the area. The legend for the number of deaths is show in the right-top corner. A Disasters around Ariake Sea and monuments by the Shimabara-Taihen, Higo-Meiwaku. The "Catastrophe" in Shimabara Area and "Annoyance" or "adversely affected" in Higo (Kumamoto) Region. $B$ The numbers of deaths are shown in the circles (the largest is 500 persons). $C$ The greatest number of deaths are in Shimabara town around the castle (5251 persons). $D$ The second largest number of deaths are in the southern part of Shimabara Peninsula (around 3500 persons). $E, F$ and $G$ Tsunami-Dome-Ishi ( $A$ stone showing the tsunami reaching that point) were set to record the tsunami by the communities in Kyodomari $(E)$, Umedo $(F)$ and Otao $(G)$ of the Higo (Kumamoto) Han area. The Tsunami-Dome-Ishi in Kyodomari was moved for the construction of a road, but its former location is marked on the road retaining wall (by the regional education committee). The Tsunami-Dome-Ishi is limited in Higo (Kumamoto) Han area. These tsunami records are reliable. $H, I$ Stone pillars for memorial services for deaths by tsunami in Futsu $(H)$ and Mie $(I)$ in Shimabara Han area locations on land and those estimated by this computer simulation were compared. The values are rather similar in 4 locations.

ICL called for cooperation for the ISDR-ICL Landslide Interactive Teaching Tools soon after the World Conference on Disaster Risk Reduction (WCDRR) in Sendai Japan and the establishment of the ISDR-ICL Sendai Partnerships for global promotion of understanding and reducing landslide disaster risk 2015-2025 on 16 March 2015. Many ICL members have offered their cooperation and contributed 


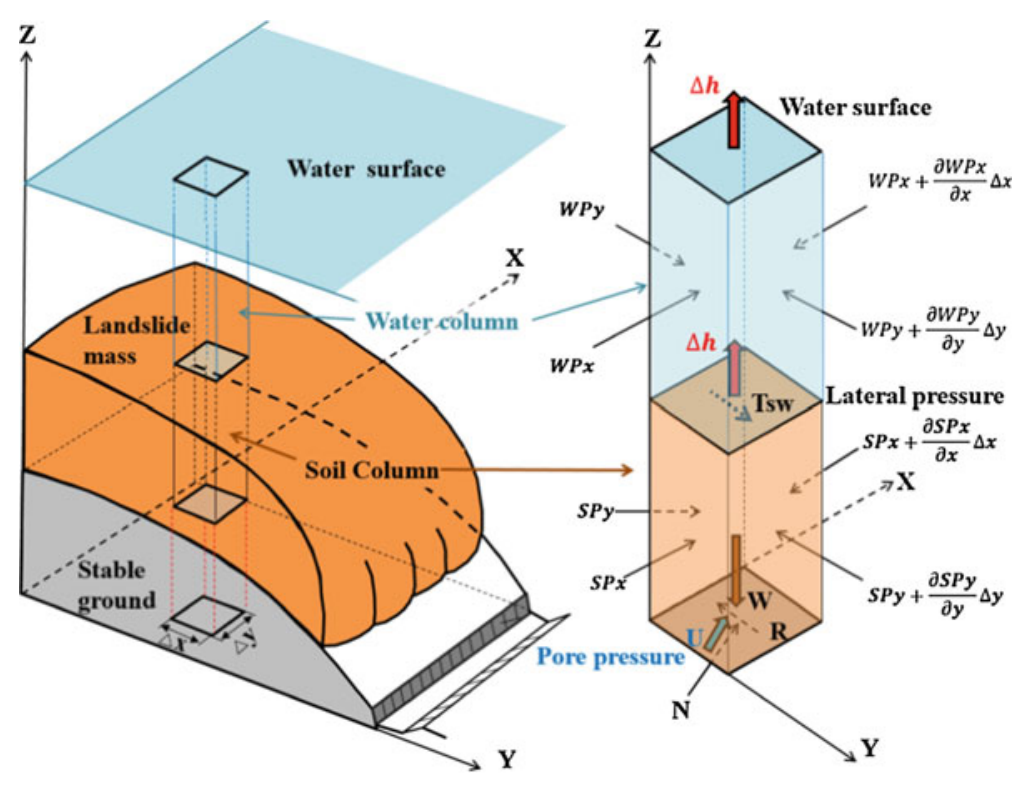

$\mathrm{a} m_{w}=\frac{\partial P_{x}}{\partial x} \Delta x+\frac{\partial P_{y}}{\partial y} \Delta y+R($ Manning $)$

Where

a: Acceleration of water column

$\mathrm{m}_{\mathrm{w}}$ : Water mass in a column

$\mathrm{R}$ (Manning): Manning's basal resistance between water and ground

Fig. 20 Basic principles of the landslide-induced tsunami simulation model

many teaching tools. ICL asked editors to evaluate those submitted tools. Tools and editors are changing during the process of producing these teaching tools. The final number of accepted teaching tools are 97 in two volumes (the total page number is 1700) and there are 11 cooperating editors. Firstly ICL appreciates all authors and their organizations which contributed teaching tools. The planned teaching tool set is not fixed, but continually evolving - it will be continuously updated, improved and enhanced by the interaction between authors and users.

The initial version of ISDR-ICL Landslide Interactive Teaching Tools will be published before the Fourth World
Landslide Forum in May 2017. The tools are expected to be improved and enhanced toward the Fifth World Landslide Forum, as well as the Sendai Partnerships mid-term conference in Japan 2020. It will be very much appreciated if voluntary contributing organizations and individuals join this initiative.

All ICL member organizations and all World Centres of Excellence for Landslide Disaster Reduction (WCoEs) and non-ICL cooperating organizations are requested to contribute to capacity building using the ISDR-ICL teaching tools and to improve these living tools as better, wider and more practical resources for landslide disaster risk reduction. 


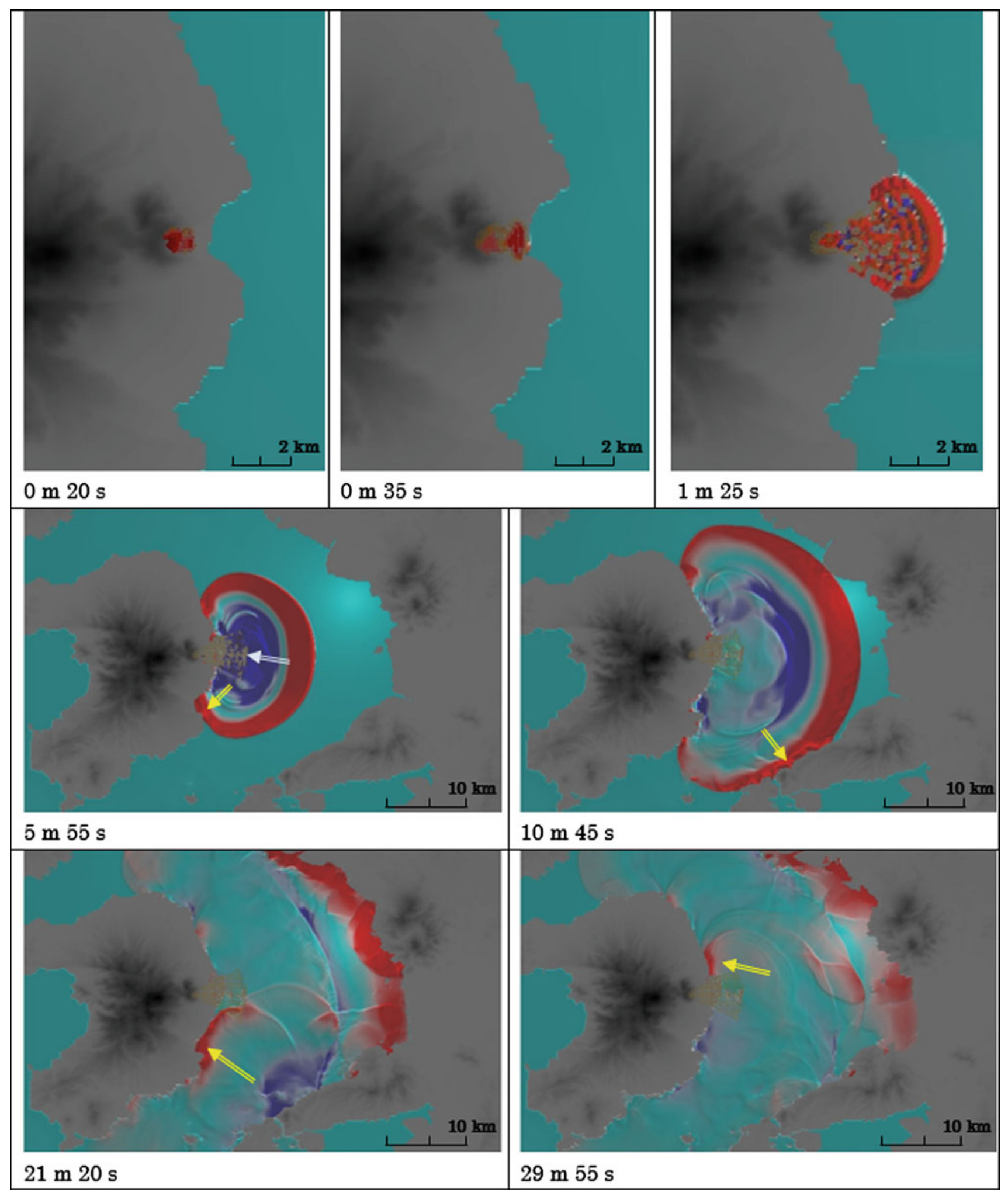

Fig. 21 LS-Tsunami simulation result for the 1792 Unzen-Mayuyama landslide-induced tsunami disaster 
Acknowledgements Acknowledgement and call for cooperation for the development of the ISDR-ICL Sendai Partnerships 2015-2025 contributing to the Sendai Framework for Disaster Risk Reduction 2015-2030.

\section{References}

Cruden DM (1991) A simple definition of a landslide. Bull Int Assoc Eng Geol 43:27-29

Cruden DM, Varnes DJ (1996) Landslide types and processes. In: Turner AK, Schuster RL (eds) Landslides investigation and mitigation. Transportation Research Board, US National Research Council. Special Report 247, Washington, DC, Chapter 3: 36-75

Dang K, Sassa K, Fukuoka H et al (2016) Mechanism of two rapid and long-runout landslides in the 16 April 2016 Kumamoto earthquake using a ring-shear apparatus and computer simulation (LS-RAPID). Landslides 13(6):1525-1534

Doan HL, Sassa K, Fukuoka H et al. (2016) Initiation mechanism of rapid and long runout landslides and simulation of hiroshima landslide disasters using the Integrated Simulation Model (LS-RAPID). TXT-Tool 3.081-1.4. Landslide dynamics: ISDR-ICL landslide interactive teaching tools, vol 1 fundamental, mapping and monitoring. Accepted

Highland LM, Bobrowsky P (2008) The landslide handbook: a guide to understanding landslides. U.S. Geological Survey Circular 1325, 129 p. http://pubs.usgs.gov/circ/1325/pdf/C1325_508.pdf

Open Access This chapter is licensed under the terms of the Creative Commons Attribution 4.0 International License (http:// creativecommons.org/licenses/by/4.0/), which permits use, sharing, adaptation, distribution and reproduction in any medium or format, as long as you give appropriate credit to the original author(s) and the source, provide a link to the Creative Commons license and indicate if changes were made.
Highland LM, Bobrowsky P (2017) Landslide types: descriptions, illustrations and Photos. TXT-Tool 0.001-2.1. Landslide Dynamics: ISDR-ICL landslide interactive teaching tools, vol 1 fundamental, mapping and monitoring. Accepted

Miyagi T, Yamashina S, Esaka F, Abe S (2010) Massive landslide triggered by 2008 Iwate-Miyagi inland earthquake in the Aratozawa Dam area, Tohoku, Japan. Landslides 8:99-108

Sassa K (2005) Landslide disasters triggered by the 2004 Mid-Niigata Prefecture earthquake in Japan. Landslides 2:135-142

Sassa K, Dang K (2016) Landslide dynamics for risk assessment. TXT-Tool 0.081-1.1. Landslide dynamics: ISDR-ICL landslide interactive teaching tools, voll fundamental, mapping and monitoring. Accepted

Sassa K, Nagai O, Solidum R et al (2010) An integrated model simulating the initiation and motion of earthquake and rain induced rapid landslides and its application to the 2006 Leyte landslide. Landslides 7(3):219-236

Sassa K, Dang K, He B, Takara K, Inoue K, Nagai O (2014) Development of a new high-stress undrained ring shear apparatus and its application to the 1792 Unzen-Mayuyama megaslide in Japan. Landslides 11(5):827-842

Sassa K, Dang K, Yanagisawa H et al (2016) A new landslide-induced tsunami simulation model and its application to the 1792 Unzen-Mayuyama landslide-and-tsunami disaster. Landslides 13 (6): 1405-1419

Varnes DJ (1978) Slope movement types and processes. In: Schuster RL, Krizek RJ (eds) Landslides, analysis and control, special report 176: Transportation Research Board. National Academy of Sciences, Washington, DC., pp 11-33

The images or other third party material in this chapter are included in the chapter's Creative Commons license, unless indicated otherwise in a credit line to the material. If material is not included in the chapter's Creative Commons license and your intended use is not permitted by statutory regulation or exceeds the permitted use, you will need to obtain permission directly from the copyright holder. 